JULIA TERESA RIBEIRO DE LIMA

AVALIAÇÃO DE MARCADORES SOROLÓGICOS, MICROBIOLÓGICOS E MOLECULARES PARA DIAGNÓSTICO DA BRUCELOSE CANINA 


\section{AVALIAÇÃO DE MARCADORES SOROLÓGICOS, MICROBIOLÓGICOS E MOLECULARES PARA DIAGNÓSTICO DA BRUCELOSE CANINA}

Tese apresentada ao Programa de Pós-Graduação em Epidemiologia Experimental Aplicada às Zoonoses da Faculdade de Medicina Veterinária e Zootecnia da Universidade de São Paulo para obtenção do título de Doutor em Ciências.

\section{Departamento:}

Medicina Veterinária Preventiva e Saúde Animal Área de concentração:

Epidemiologia Experimental Aplicada às Zoonoses

Orientador(a):

Profa. Dra. Lara Borges Keid

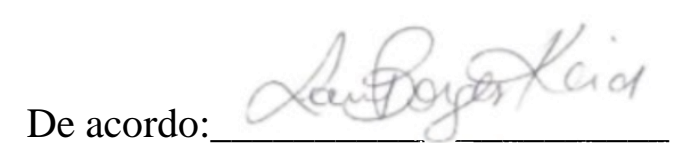

Orientador

\section{São Paulo}

2018

Obs: A versão original encontra-se disponível na Biblioteca da FMVZ/USP 
Autorizo a reprodução parcial ou total desta obra, para fins acadêmicos, desde que citada a fonte.

DADOS INTERNACIONAIS DE CATALOGAÇÃO NA PUBLICAÇÃO

(Biblioteca Virginie Buff D’Ápice da Faculdade de Medicina Veterinária e Zootecnia da Universidade de São Paulo)

\begin{tabular}{|l}
$\begin{array}{l}\text { T. 3597 } \\
\text { FMVZ }\end{array}$ \\
$\begin{array}{l}\text { Lima, Julia Teresa Ribeiro de } \\
\text { Avaliação de marcadores sorológicos, microbiológicos e moleculares para diagnóstico } \\
\text { da brucelose canina / Julia Teresa Ribeiro de Lima. - } 2018 . \\
71 \text { f. : il. }\end{array}$ \\
$\begin{array}{l}\text { Tese (Doutorado) - Universidade de São Paulo. Faculdade de Medicina Veterinária e } \\
\text { Zootecnia. Departamento de Medicina Veterinária Preventiva e Saúde Animal, São Paulo, } \\
2018 .\end{array}$ \\
Programa de Pós-Graduação: Epidemiologia Experimental Aplicada às Zoonoses. \\
Área de concentração: Epidemiologia Experimental Aplicada às Zoonoses. \\
Orientadora: Profa. Dra. Lara Borges Keid. \\
1. Brucella canis. 2. Cães. 3. Diagnóstico. 4. Aspirado de linfonodo. 5. Ensaio \\
imunocromatográfico. I. Título.
\end{tabular}

Ficha catalográfica elaborada por Camila Molgara Gamba, CRB 7070-8. 


\section{CERTIFICADO}

Certificamos que a proposta intitulada "AVALIAÇÃO DE MARCADORES SOROLÓGICOS, MICROBIOLÓGICOS E MOLECULARES PARA O DIAGNÓSTICO DA BRUCELOSE CANINA", protocolada sob o CEUA no 1534060215, sob a responsabilidade de Lara Borges Keid $e$ equipe; Julia Teresa Ribeiro de Lima - que envolve a produção, manutenção e/ou utilização de animais pertencentes ao filo Chordata, subfilo Vertebrata (exceto o homem), para fins de pesquisa científica ou ensino - está de acordo com os preceitos da Le 11.794 de 8 de outubro de 2008, com o Decreto 6.899 de 15 de julho de 2009, bem como com as normas editadas pelo Conselho Nacional de Controle da Experimentação Animal (CONCEA), e foi aprovada pela Comissão de Ética no Uso de Animais da Faculdade de Medicina Veterinária e Zootecnia da Universidade de São Paulo (CEUA/FMVZ) na reunião de 13/10/2015.

We certify that the proposal "EVALUATION OF SEROLOGIC, MICROBIOLOGIC AND MOLECULAR MARKERS FOR CANINE BRUCELLOSIS DIAGNOSIS", utilizing 160 Dogs (80 males and 80 females), protocol number CEUA 1534060215, under the responsibility of Lara Borges Keid and team; Julia Teresa Ribeiro de Lima - which involves the production, maintenance and/or use of animals belonging to the phylum Chordata, subphylum Vertebrata (except human beings), for scientific research purposes or teaching - is in accordance with Law 11.794 of October 8, 2008, Decree 6899 of July 15, 2009, as well as with the rules issued by the National Council for Control of Animal Experimentation (CONCEA), and was approved by the Ethic Committee on Animal Use of the School of Veterinary Medicine and Animal Science (University of São Paulo) (CEUA/FMVZ) in the meeting of 10/13/2015.

Finalidade da Proposta: Pesquisa

Vigência da Proposta: de MAR/201 a JUL/201

Área: Medicina Veterinária Preventiva E Saúde Animal

Origem:

\begin{tabular}{llclc}
$\begin{array}{l}\text { Espécie: } \\
\text { Linhagem: }\end{array}$ & Cães & sexo: Machos & $\begin{array}{l}\text { idade: a } \\
\text { Peso: a }\end{array}$ & $\mathrm{N}: 80$ \\
\hline $\begin{array}{l}\text { Origem: } \\
\text { Espécie: }\end{array}$ & Cães & sexo: Fêmeas & $\begin{array}{l}\text { idade: a } \\
\text { Peso: a }\end{array}$ & $\mathrm{N}:$ \\
Linhagem: & $\mathrm{N} / \mathrm{A}$ & & 80 \\
\hline
\end{tabular}

Resumo: A brucelose é uma zoonose de distribuição mundial que causa diminuição da eficiência reprodutiva e aborto em espécies domésticas e silvestres. Devido seu caráter zoonótico, é importante a identificação das fontes de infecção, a fim de orientar a tomada de decisão para o bloqueio da transmissão ao ser humano e a outros animais susceptíveis. Atualmente, o gênero Brucella é composto por dez espécies, sendo que cada uma delas possui uma espécie hospedeira preferencial. A brucelose causada pela Brucella canis constitui uma infecção sistêmica, caracterizada por bacteremia prolongada e caráter zoonótico que acomete principalmente os cães, sendo responsável por problemas reprodutivos nesta espécie. A identificação dos cães doentes é importante, pois esses animais constituem fontes de infecção, uma vez que podem eliminar o agente no ambiente por secreções e excreções corporais. A presença de sinais clínicos pode sugerir infecção por Brucella, contudo, é importante ressaltar que uma porcentagem considerável dos cães infectados é assintomática, o que torna o diagnóstico laboratorial essencial para a confirmação. Ensaios imunoenzimáticos utilizando proteínas recombinantes de Brucella spp. como antígenos foram propostos para o diagnóstico da brucelose, tendo como vantagem o uso de um antígeno mais purificado e maior especificidade na detecção da infecção. Dentre as proteínas recombinantes empregadas no diagnóstico da brucelose canina, temos a proteína BP26, uma proteína citoplasmática de Brucella spp. de 28-kDa que apresenta sensibilidade superior aos demais testes na detecção de animais infectados em ausência de bacteremia e também na detecção de animais suspeitos por serem contactantes de cães positivos, sugerindo que este antígeno possa ter potencial para o diagnóstico de animais cronicamente infectados. Em razão dos problemas de sensibilidade e especificidade observados nos testes sorológicos aplicados ao diagnóstico da brucelose nos cães, o diagnóstico definitivo da infecção deve basear-se sempre na associação de métodos indiretos com métodos diretos de diagnóstico. 0 cultivo microbiológico constitui importante ferramenta para a detecção de animais bacterêmicos, porém, apresenta limitações na detecção de infecções crônicas. A PCR vem sendo empregada como instrumento para o aprimoramento do diagnóstico da brucelose, por apresentar maior sensibilidade em relação aos métodos bacteriológicos e alta especificidade pela utilização de primers específicos. Além disso, pode ser empregada para a detecção de Brucella em vários tipos de amostras biológicas provenientes de diversas espécies hospedeiras. Após a infecção do animal suscetível, as brucelas disseminam-se para os órgãos linfoides no interior de macrófagos, de maneira que a utilização de amostras aspirados de linfonodos e de suabes de conjuntiva no cultivo microbiológico e na PCR poderia aumentar a chance de detecção do patógeno, inclusive durante infecções crônicas. O controle e profilaxia da Brucella canis em populações de cães envolve alguns procedimentos como a confirmação do diagnóstico através de testes sorológicos e bacteriológicos, quarentena, identificação e eliminação dos animais infectados além da implantação de práticas para

Av. Prof. Dr. Orlando Marques de Paiva, 87, Cidade Universitária: Armando de Salles Oliveira CEP 05508-270 São Paulo/SP - Brasil - tel: 55 (11) $3091-7676$ / fax: 55 (11) $3032-2224$ Horário de atendimento: $2^{\mathrm{a}}$ a $5^{\mathrm{a}}$ das $7 \mathrm{~h} 30$ às $16 \mathrm{~h}$ : e-mail: ceuavet@usp.br CEUA N 1534060215 
a prevenção de futuros surtos. Como não há vacina disponível para prevenir a infecção e o tratamento com antimicrobianos tem baixa eficiência em eliminar o agente, a profilaxia da brucelose nos cães é baseada principalmente no diagnóstico laboratorial para identificar animais infectados. Assim, a avaliação de marcadores de infecção que possibilitem a identificação de animais acometidos nas diferentes fases da infecção é imprescindível para o sucesso das medidas profiláticas. Na presente proposta, pretende-se avaliar métodos sorológicos, microbiológicos e moleculares como marcadores de infecção que possibilitem aumentar a sensibilidade na detecção de cães infectados por B. canis na ausência e presença de bacteremia.

Local do experimento:

São Paulo, 22 de dezembro de 2017

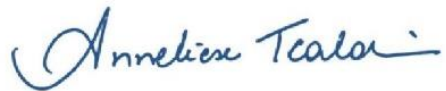

Profa. Dra. Anneliese de Souza Traldi Presidente da Comissão de Ética no Uso de Animais Faculdade de Medicina Veterinária e Zootecnia da Universidad de São Paulo

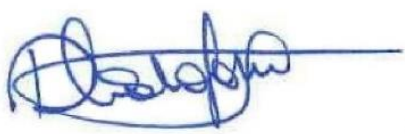

Roseli da Costa Gomes Secretária Executiva

Faculdade de Medicina Veterinária e Zootecnia da Universidade de São Paulo 


\section{FOLHA DE AVALIAÇÃO}

Nome: Lima, Julia Teresa Ribeiro de

Título: Avaliação de Marcadores Sorológicos, Microbiológicos e Moleculares para Diagnóstico da Brucelose Canina

Tese apresentada ao Programa de Pós-Graduação em Epidemiologia Experimental Aplicada às Zoonoses da Faculdade de Medicina Veterinária e Zootecnia da Universidade de São Paulo para obtenção do título de Doutor em Ciências.

Data:

\section{BANCA EXAMINADORA}

Prof. Dr.

Instituição: Julgamento:

Prof. Dr.

Instituição: Julgamento:

Prof. Dr.

Instituição: Julgamento:

Prof. Dr.

Instituição: Julgamento:

Prof. Dr.

Instituição: Julgamento: 


\section{DEDICATÓRIA}

Por fazer meus dias mais felizes;

Por me apresentar o maior amor do mundo;

Por transformar minha vida e me fazer uma pessoa melhor;

Por me conceder o título mais bonito,

dedico este trabalho à minha filha Cecília. 


\section{AGRADECIMENTOS}

Agradeço aos meus pais pela confiança e por estarem sempre incentivando e apoiando as minhas decisões;

Ao Fernando Silveira Marques pelo companheirismo, apoio, paciência e pelas palavras de incentivo nos momentos mais difíceis;

À minha orientadora, Dra. Lara Borges Keid, pela oportunidade e confiança e pelos ensinamentos fundamentais para a minha formação. Agradeço ainda pelo apoio oferecido nos momentos em que mais precisei;

A todos os professores da FMVZ-USP e FZEA-USP que contribuíram com de forma significativa para a minha formação;

A todos os colegas da FMVZ-USP e FZEA-USP pela amizade, companhia e convívio, proporcionando momentos agradáveis durante estes anos;

Ao Departamento de Medicina Veterinária Preventiva e Saúde Animal da Faculdade de Medicina Veterinária e Zootecnia da Universidade de São Paulo e a todos os seus funcionários;

Ao Conselho Nacional de Desenvolvimento Científico e Tecnológico (CNPq) pelo auxílio financeiro processo 142093/2014-9. 


\section{RESUMO}

LIMA, J.T.R. Avaliação de marcadores sorológicos, microbiológicos e moleculares para diagnóstico da brucelose canina. [Evaluation of serological, microbiological and molecular markers for canine brucellosis diagnosis]. 2018. 71 f. Tese (Doutorado em Ciências) Faculdade de Medicina Veterinária e Zootecnia, Universidade de São Paulo, São Paulo, 2018.

A brucelose causada pela $B$. canis constitui uma infecção sistêmica e zoonótica que acomete principalmente os cães, causando problemas reprodutivos. O diagnóstico da infecção é difícil, sendo necessária a associação do diagnóstico clínico aos métodos laboratoriais diretos e indiretos para sua confirmação. Um dos problemas relativos ao diagnóstico laboratorial está relacionado à ausência de marcadores que possibilitem a identificação acurada de cães em ausência de bacteremia. A partir do exposto, foi realizado um estudo com o objetivo de avaliar o desempenho de testes laboratoriais diretos e indiretos como marcadores da infecção por $B$. canis em cães e determinar a combinação de testes que possibilite o diagnóstico da brucelose canina com maiores valores de sensibilidade e especificidade. Foram coletadas amostras de sangue, soro e aspirado de linfonodo de 92 cães, sem distinção de sexo, idade ou raça, incluindo cães reprodutores e não reprodutores. A hemocultura e a reação em cadeia pela polimerase (PCR) foram previamente realizadas nas amostras de sangue e, com base nos resultados, os 92 animais foram divididos em dois grupos: infectados $(n=37)$ e não infectados $(n=55)$. Em seguida, as amostras de aspirado de linfonodo foram submetidas à PCR e ao cultivo microbiológico e as amostras de soro foram testadas por um ensaio imunocromatográfico (EIC). A partir dos resultados obtidos, a sensibilidade e especificidade diagnóstica dos testes foram calculadas utilizando os grupos infectados e não infectados, respectivamente. O coeficiente Kappa foi usado para calcular a concordância entres os testes laboratoriais e suas combinações. A proporção de resultados positivos foi de 40,2\% (37/92) para os testes diretos em amostras de sangue, $29 \%$ (27/92) e 25\% (23/92) para PCR e cultivo em amostras de aspirado de linfonodo, respectivamente, e 43\% (40/92) para o EIC. A concordância entre os testes variou de moderada a quase perfeita. A sensibilidade e especificidade diagnóstica foram, respectivamente, $65 \%$ e 95\% para PCR em amostras de aspirado de linfonodo, $62 \%$ e $100 \%$ para o cultivo microbiológico em amostras de aspirado de linfonodo e $92 \%$ e $89 \%$ para o EIC. A PCR em amostras de aspirados de linfonodos apresentou maior sensibilidade em relação ao cultivo aplicado a estas amostras, sendo uma alternativa ao diagnóstico microbiológico. A associação 
entre os testes de PCR em amostras de aspirados de linfonodos e de sangue e o EIC possibilitou um aumento da sensibilidade diagnóstica, por possibilitar a identificação de cães na ausência e na presença de bacteremia, com maior rapidez.

Palavras-chave: Brucella canis. Cães. Diagnóstico. Aspirado de linfonodo. Ensaio imunocromatográfico. 


\begin{abstract}
LIMA, J.T.R. Evaluation of serological, microbiological and molecular markers for canine brucellosis diagnosis. [Avaliação de marcadores sorológicos, microbiológicos e moleculares para diagnóstico da brucelose canina]. 2018. 71 f. Tese (Doutorado em Ciências) - Faculdade de Medicina Veterinária e Zootecnia, Universidade de São Paulo, São Paulo, 2018.
\end{abstract}

Brucellosis caused by B. canis is a systemic and zoonotic infection characterized by prolonged bacteremia that affects mainly dogs causing reproductive problems. The diagnosis of the infection is quite difficult, being necessary the association of the clinical diagnosis with direct and indirect laboratory methods to confirm the infection. The main drawback regarding the laboratory diagnosis relies on the lack of markers that allow the accurate identification of non bacteremic dogs. From the above, a study was carried out to evaluate the performance of direct and indirect laboratory tests as markers for B. canis infection in dogs and to determine the combination of tests that allows the diagnosis of the infection with higher values of sensitivity and specificity. Samples of blood, serum and lymph node aspirates were collected from $92 \mathrm{dogs}$, regardless the sex, age or breed, including pet and breeding dogs. All the dogs were tested using culturing and the polymerase chain reaction (PCR) in blood samples and, based on the results, they were divided into two groups: infected $(n=37)$ and non-infected $(n=55)$. Lymph node aspirates were tested through PCR and microbiological culturing, and serum samples using an immunochromatographic assay (EIC). The infected and uninfected groups were used to calculate, respectively, the sensitivity and specificity of the tests. The agreement between the tests was calculated using Kappa coefficient. The proportion of positive results was $40.2 \%$ (37/92) for the direct tests in blood samples, 29\% (27/92) and 25\% (23/92) for PCR and lymph node culturing, respectively, and 43\% (40/92) for the EIC. The agreement between the tests ranged from moderate to near perfect. The sensitivity and specificity was, respectively, $65 \%$ and $95 \%$ for PCR in lymph node aspirates, $62 \%$ and $100 \%$ for lymph node culturing, and $92 \%$ and $89 \%$ for EIC. The PCR in lymph node aspirates showed a higher sensitivity when compared to the lymph node culturing, being an alternative to the microbiological diagnosis. The association between PCR in blood and lymph node aspirates and the EIC enabled an increased sensitivity in the diagnosis with the identification of non-bacteremic dogs more rapidly.

Keywords: Brucella canis. Dogs. Diagnosis. Lymph nodes aspirates. Immunochromatographic assay. 


\section{LISTA DE ABREVIATURAS E SÍMBOLOS}

2ME - 2-mercaptoetanol

CTAB - hexadecyltrimethylammonium

bromide

dATP - desoxi-adenosina trifosfato

dCTP - desoxi-citosina trifosfato

dGTP - desoxi-guanosina trifosfato

dTTP - desoxi-timidina trifosfato

DNA - ácido desoxirribonucléico

EDTA - ácido etileno-diamino-tetracético

EIC - ensaio imunocromatográfico

ELISA - ensaio imunoenzimático

fg - fentograma

g - grama

g - gravidade

$\mathrm{HCl}$ - ácido clorídrico

IDGA - imunodifusão em gel de ágar

IgG - imunoglobulina $\mathrm{G}$

IgM - imunoglobulina M

IS - Insertion sequence

ITS - internal transcribed sequence

K - Kappa

$\mathrm{KCl}$ - cloreto de potássio

L - litro

LPS - lipopolissacarídeos

LS - Lumazine Synthase

M - molar (mol por litro)

mg - miligrama

$\mathrm{MgCl} 2$ - cloreto de magnésio

$\mathrm{mL}$ - mililitro

mm - milímetro $\mu \mathrm{M}$ - micromolar

mM - milimolar

$\mu \mathrm{g}$ - micrograma

$\mu \mathrm{L}$ - microlitro

$\mathrm{NaCl}$ - Cloreto de sódio

nm - nanômetro

Omp31 - outer membrane protein 31

$\mathrm{PC}$ - proteína citoplasmática

PCR - reação em cadeia pela polimerase

pg - picograma

$\mathrm{pH}$ - potencial hidrogeniônico

R-LPS - lipopolissacarídeo rugoso

RNA - ácido ribonucléico

rpm - rotações por minuto

SAL - prova de soroaglutinação lenta

SAR - prova de soroaglutinação rápida

SAR-2ME - soroaglutinação rápida com

2-mercaptoetanol

Taq - Thermus aquaticus

TBE - tris-borato-EDTA

TE - tampão Tris-EDTA

TRIS - Tris (hidroximetil) amino metano

Tris $\mathrm{HCl}$ - Tris (hidroximetil) amino

metano com ácido clorídrico

Tris-borato - Tris (hidroximetil) amino

metano com borato

UI - unidade internacional

V - volts

$\mathrm{X}$ - vezes 


\section{LISTA DE FIGURAS}

Figura 1. Diluição da amostra de DNA de Brucella canis em solução TE ou em amostras de DNA canino a partir de cães negativos para Brucella sp......................................... 36 


\section{LISTA DE GRÁFICOS}

Gráfico 1. Estimativas pontuais e intervalares da sensibilidade e especificidade diagnóstica dos testes realizados neste trabalho. 


\section{LISTA DE QUADROS}

Quadro 1. Sequência dos primers direcionados à sequência de inserção 711 (IS711) utilizados para detecção de Brucella spp. pela reação em cadeia pela polimerase.. 37 


\section{LISTA DE TABELAS}

Tabela 1. Proporção de resultados positivos obtidos pelos testes laboratoriais diretos utilizados em amostras de sangue, pela reação em cadeia pela polimerase (PCR), cultivo microbiológico direto e cultivo microbiológico com enriquecimento em caldo nas amostras de aspirado de linfonodo e pelo ensaio imunocromatográfico (EIC) em amostras de soros dos cães examinados e suas combinações.

Tabela 2. Comparação dos resultados obtidos com o cultivo microbiológico direto, cultivo em caldo e reação em cadeia pela polimerase (PCR) de aspirados de linfonodos, hemocultura e/ou PCR em sangue e ensaio sorológico imunocromatográfico (EIC), analisados pelo coeficiente Kappa, separadamente e em combinações, para o diagnóstico da brucelose canina em 92 cães.

Tabela 3. Sensibilidade e especificidade diagnóstica da PCR aplicada em amostras de aspirados de linfonodos caninos para diagnóstico de infecção por Brucella canis (situação 1)

Tabela 4. Sensibilidade e especificidade diagnóstica do cultivo microbiológico para isolamento de Brucella canis em amostras de aspirados de linfonodos caninos, utilizando-se protocolo de cultivo direto em ágar (situação 2).

Tabela 5. Sensibilidade e especificidade diagnóstica do cultivo microbiológico para isolamento de Brucella canis em amostras de aspirados de linfonodos caninos, utilizando-se protocolo de enriquecimento em caldo (situação 3).

Tabela 6. Sensibilidade e especificidade diagnóstica do cultivo microbiológico geral para isolamento de Brucella canis em amostras de aspirados de linfonodos caninos (situação 4)....

Tabela 7. Sensibilidade e especificidade diagnóstica do diagnóstico direto aplicado à detecção de Brucella canis em amostras de aspirados de linfonodos caninos (

Tabela 8. Sensibilidade e especificidade diagnóstica do ensaio imunocromatográfico (EIC) utilizado para o diagnóstico sorológico da infecção por Brucella canis em 92 cães.

Tabela 9. Sensibilidade e especificidade diagnóstica considerando-se conjuntamente os resultados obtidos no EIC e no teste direto para detecção de Brucella canis em amostras de aspirados de linfonodos. 


\section{SUMÁRIO}

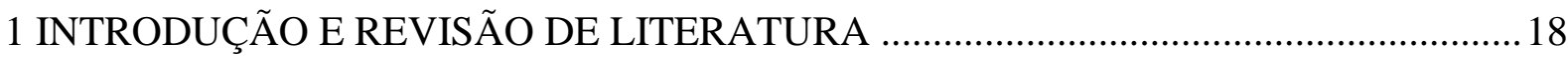

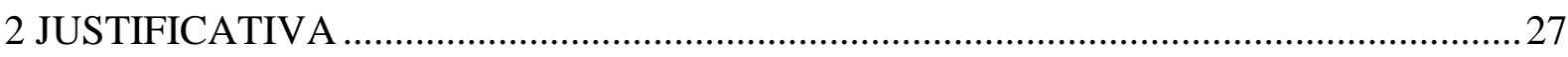

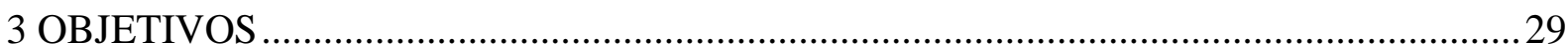

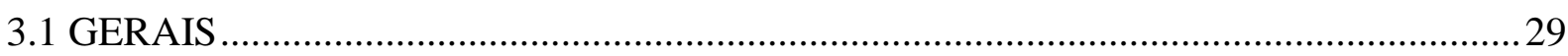

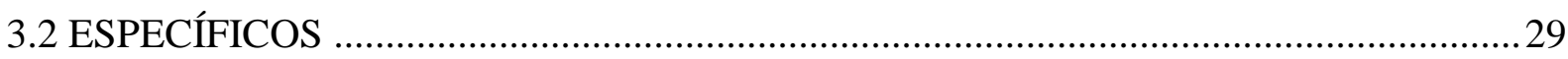

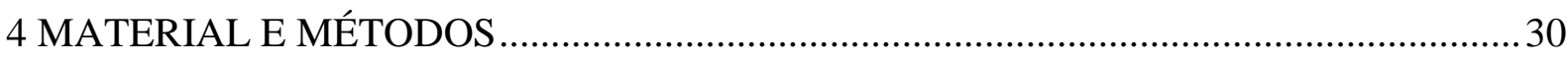

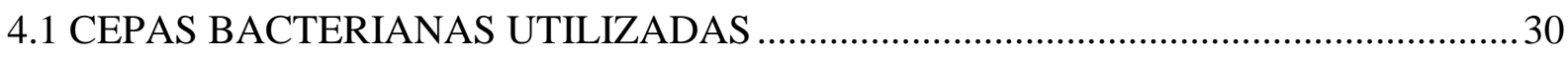



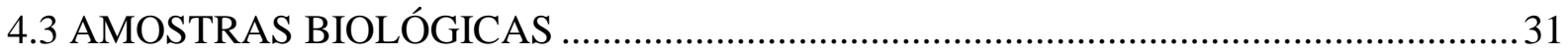

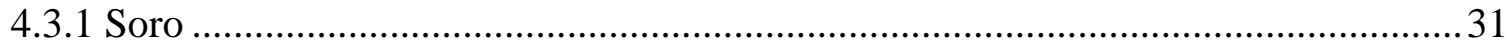

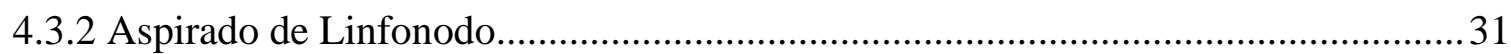

4.4 CULTIVO MICROBIOLÓGICO DAS AMOSTRAS DE ASPIRADOS DE

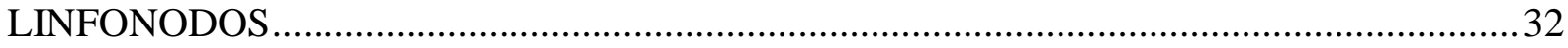

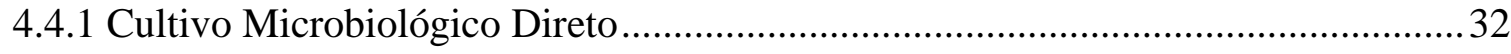

4.4.2 Cultivo Microbiológico com Enriquecimento em Meio Líquido (caldo) ................. 32



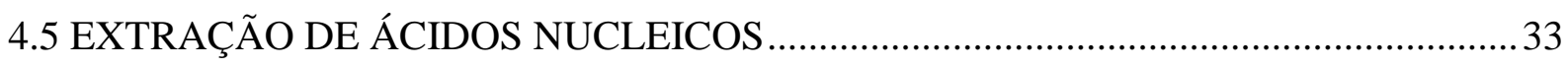

4.5.1 Extração de Ácidos Nucleicos da Cepa de Referência de B. canis...........................33

4.5.2 Extração de Ácidos Nucleicos das Colônias Bacterianas Isoladas de Aspirados de

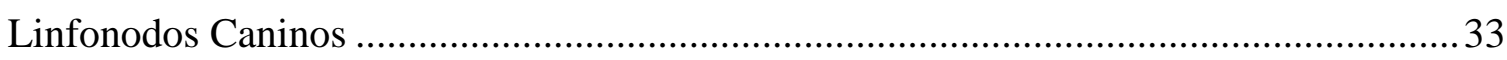

4.5.3 Extração de Ácidos Nucleicos das Amostras de Aspirado de Linfonodos ............... 34

4.6 QUANTIFICAÇÃO DE DNA E PREPARO DAS DILUIÇÕES SERIADAS DE DNA

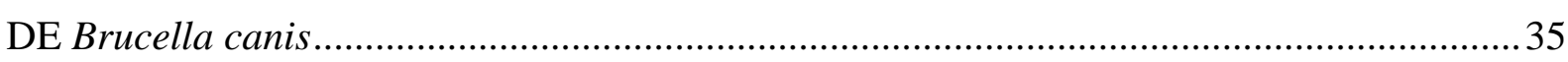

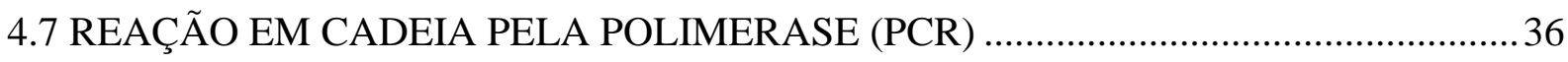

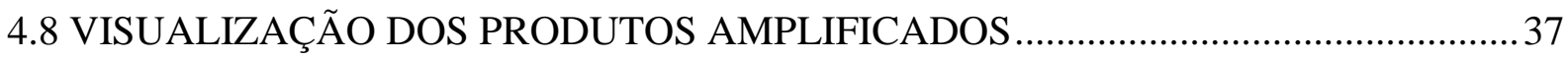

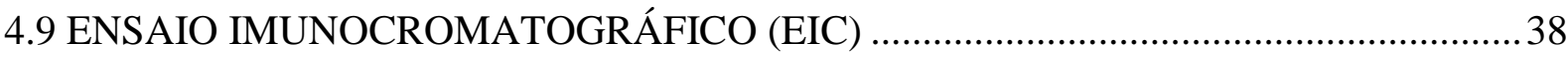


4.10 ANÁLISE DE SENSIBILIDADE E ESPECIFICIDADE DIAGNÓSTICA DOS



4.11 ANÁLISE DE CONCORDÂNCIA DAS PROVAS DE DIAGNÓSTICO .....................39

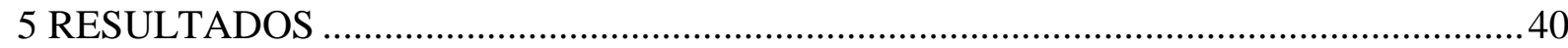

5.1 SENSIBILIDADE ANALÍTICA DA PCR UTILIZANDO OS PRIMERS IS711 EM

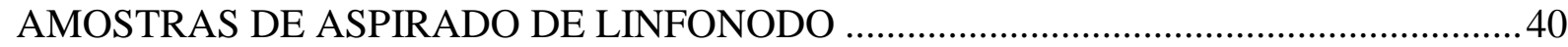

5.2 PROPORÇÃO DE RESULTADOS POSITIVOS PELOS MÉTODOS DE

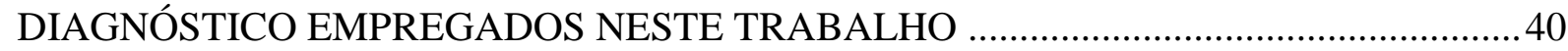

5.3 CONCORDÂNCIA ENTRE OS TESTES LABORATORIAIS UTILIZADOS ...............40 5.4 SENSIBILIDADE E ESPECIFICIDADE DIAGNÓSTICA DOS TESTES REALIZADOS

6 DISCUSSÃO 49

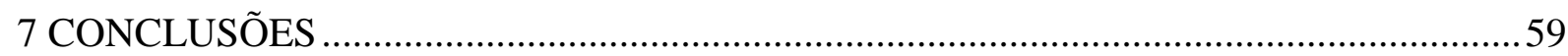

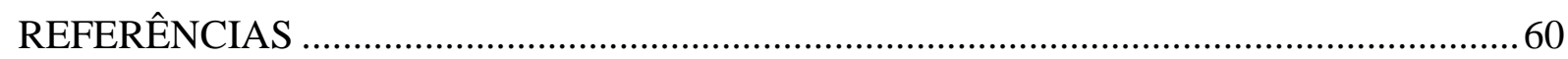




\section{INTRODUÇÃO E REVISÃO DE LITERATURA}

A brucelose é uma doença infectocontagiosa de evolução crônica provocada por uma bactéria intracelular facultativa pertencente ao gênero Brucella. A infecção é sistêmica, comprometendo muitos órgãos e tecidos (REDKAR et al., 2001) e causando diminuição da capacidade reprodutiva e abortamento em espécies domésticas e silvestres. Além de acarretar grande impacto econômico, possui importância na saúde pública e animal, visto que afeta diversas espécies animais e pode ser transmitida também aos seres humanos. Nos animais a infecção está relacionada a problemas reprodutivos e no homem geralmente produz quadros característicos de infecção generalizada (PAULIN; FERREIRA NETO, 2003).

O gênero Brucella é composto por diversas espécies que, embora sejam capazes infectar diferentes espécies animais, cada uma delas mostra preferência por um determinado hospedeiro. Dentre elas, seis são consideradas clássicas (CLAVAREAU et al., 1998; FOSTER et al., 2007; SCHOLZ et al., 2008, 2010): Brucella melitensis, responsável pela brucelose ovina e caprina, sendo considerada a mais virulenta; B. abortus, principal agente da brucelose bovina e bubalina; B. suis causa brucelose em suínos, lebres e renas; B. canis, responsável pela brucelose canina; A espécie $B$. ovis é espécie-específica, sendo responsável por transtornos reprodutivos apenas em ovinos (ALTON et al., 1976; VIZCAÍNO et al., 2000; ACHA; SZYFRES, 2001); B. neotomae foi isolada de roedores pertencentes à espécie Neotoma lepida nos Estados Unidos (STOENNER; LACKMAN, 1957).

Além das seis espécies bacterianas clássicas mencionadas, outras espécies e variantes foram isoladas de vários hospedeiros como $B$. ceti e $B$. pinnipedialis de mamíferos marinhos (CLAVAREAU et al., 1998; FOSTER et al., 2007), B. microti de roedores silvestres da espécie Microtus arvalis e de canídeos Vulpes vulpes, tendo sido também isolada de amostras de solo na Europa (SCHOLZ et al., 2008), B. inopinata foi isolada de implante de prótese mamária de uma paciente humana com sinais clínicos de brucelose, sendo que o reservatório desta espécie ainda não foi definido (SCHOLZ et al., 2010). Mais recentemente foram identificadas novas espécies pertencentes ao gênero Brucella: a espécie B. papionis foi associada a abortamentos em babuínos (Papio sp.) nos Estados Unidos (WHATMORE et al., 2014) e B. vulpis foi primeiramente identificada na Áustria com isolamentos descritos em raposa vermelha ( $V$. vulpes) (SCHOLZ et al., 2016a). Além destas, cepas de Brucella foram isoladas de anfíbios 
pertencentes a inúmeras espécies em diversas localidades geográficas, bem como de arraia da espécie Taeniura lymma (EISENBERG et al., 2017), indicando que a amplitude de hospedeiros animais do gênero possa incluir também animais de sangue frio (SCHOLZ et al., 2016b).

Do ponto de vista antigênico, as bactérias do gênero Brucella são divididas em dois grupos: as lisas, como B. abortus, B. melitensis e B. suis, e as rugosas, como B. ovis e B. canis (METCALF et al., 1994; QUINN et al., 1994; CORBEL, 1997; CORBEL; BANAI, 2005). Esta classificação é baseada na composição do lipopolissacarídeo (LPS) na parede celular. Nas lisas, o LPS possui o lipídeo A, ancorado na membrana externa, um núcleo composto por oligossacarídeos e a cadeia $\mathrm{O}$, que é a estrutura mais externa da parede celular. Já as rugosas possuem apenas lipídeo A e o núcleo de oligossacarídeos, sendo a cadeia $\mathrm{O}$ ausente (CORBEL, 1997).

Este gênero de bactérias se replica em fagócitos mononucleares do hospedeiro e compreende uma série de fatores de virulência que possibilitam sua evasão da resposta imune (SALDARRIAGA; OSSA, 2002). O agente invade o hospedeiro pelas mucosas oronasal, genital, conjuntival ou mesmo por soluções de continuidade da pele. Após a penetração no organismo do hospedeiro, as brucelas são fagocitadas por macrófagos e outras células fagocitárias, onde sobrevivem e multiplicam-se, sendo posteriormente transportadas aos linfonodos regionais provocando linfadenopatia periférica. $\mathrm{O}$ organismo atinge a circulação sanguínea sucedendo bacteremia e disseminação preferencialmente para tecidos ricos em esteróides gonadais como útero de fêmeas gestantes, próstata, epidídimos e testículos e em células reticuloendoteliais, como baço, fígado, linfonodos e medula óssea (CARMICHAEL; KENNEY, 1970; NIELSEN; DUNCAN, 1990; JOHNSON; WALKER, 1992; QUINN et al., 1994; GREENE; CARMICHAEL, 2006).

A brucelose causada pela $B$. canis constitui uma infecção sistêmica, caracterizada por bacteremia prolongada e caráter zoonótico que acomete principalmente os cães, sendo responsável por problemas reprodutivos como abortamento, falhas de concepção, orquite, epididimite e infertilidade nesta espécie. Sinais clínicos não reprodutivos podem ser observados associados aos tecidos ricos em células reticuloendoteliais e tecidos articulares e infecções assintomáticas também podem ser observadas ( CARMICHAEL; GREENE, 1990; KEID et al., 2007).

Nos seres humanos, os principais sinais clínicos observados são: febre prolongada, fadiga, aumento do volume dos linfonodos (CARMICHAEL; GREENE, 1990), tosse, dores 
articulares (GODOY et al., 1979), cefaleia, náuseas, sudorese noturna (CARMICHAEL, 1990; ROXO et al., 1990), mialgia e depressão (ROXO et al., 1990).

Seu caráter zoonótico foi constatado na década de 60, após a notificação de casos de infecção em seres humanos ocasionados por acidentes em laboratório, confirmados através de evidências sorológicas e isolamento do agente (MORISSET; SPINK, 1969). Desde então, casos de infecção humana por B. canis vem sendo descritos, tanto adquiridas em laboratórios como doença ocupacional (GODOY et al., 1979; WALLACH et al., 2004), quanto decorrentes do contato direto com cães infectados (BLANKENSHIP; SANFORD, 1975; LUCERO et al., 2005a, 2005b, 2010a; NOMURA et al., 2010; DENTINGER et al., 2015). Há ainda casos de infecção em humanos nos quais a fonte de infecção não foi identificada (POLT et al., 1982; ROUSSEAU, 1985; GREENE; CARMICHAEL, 2006; ANGEL et al., 2012).

No Brasil, a brucelose canina é endêmica e a presença de cães infectados por Brucella spp. foi confirmada tanto por investigações microbiológicas (KEID et al., 2002, 2004, 2017; MEGID et al., 2008; LUCERO et al., 2010b), como por inquéritos sorológicos (MORAES, C. C. G. et al., 2002; MORAES, I. A. et al., 2002; AZEVEDO et al., 2003; ALMEIDA et al., 2004; AGUIAR et al., 2005; MEGID et al., 2008; LUCERO et al., 2010b). Observa-se uma ocorrência variando entre $0,8 \%$ e $72,7 \%$, de acordo com a região, a população de cães examinada e o teste de diagnóstico empregado (KEID et al., 2004; MALEK DOS REIS et al., 2008; VASCONCELOS et al., 2008; DORNELES et al., 2011; BEZERRA et al., 2012; SILVA et al., 2012).

Cães infectados por B. canis podem eliminar o agente no ambiente por secreções vaginais, fetos abortados, ejaculados, pela urina ou pelas fezes. Em função do estreito convívio estabelecido entre os cães e o homem, a brucelose canina apresenta importância do ponto de vista da saúde pública já que humanos podem se infectar por B. canis, quando em contato com animais infectados e suas secreções (LUCERO et al., 2005a, 2010a). Além disso, em canis comerciais, a brucelose canina representa um grande risco, podendo causar perdas econômicas decorrentes de abortamento e infertilidade, assim como de perda de patrimônio genético decorrente da infecção em animais de alto valor genético (JONES; EMERSON, 1984; KEID et al., 2004).

A infecção dos cães por espécies lisas de Brucella pode ocorrer quando do contato destes com bovinos, suínos e caprinos infectados. Os cães podem adquirir a infecção pela ingestão de 
leite in natura ou de tecidos animais, restos placentários ou de fetos abortados contaminados (AZEVEDO et al., 2003; MIRANDA et al., 2005).

Devido à ausência de sinais específicos e à possibilidade de infecções assintomáticas, o diagnóstico clínico da brucelose canina pode ser difícil, sendo necessário associar a presença de sinais clínicos sugestivos aos métodos laboratoriais indiretos e diretos para a confirmação da infecção (FORBES, 1990; WANKE, 2004).

Os testes laboratoriais indiretos rotineiramente utilizados para o diagnóstico da brucelose baseiam-se na detecção de anticorpos específicos presentes no soro sanguíneo dos animais infectados (ALTON et al., 1976). O sorodiagnóstico da brucelose canina atualmente pode ser realizado empregando-se as seguintes provas: soroaglutinação rápida (SAR) (BADAKHSH et al., 1982; CARMICHAEL; JOUBERT, 1987), soroaglutinação lenta (SAL) (ALTON et al., 1976), imunodifusão em gel de ágar (IDGA) (MYERS et al., 1974), ensaio imunoenzimático (ELISA) (WANKE et al., 2002; ZYGMUNT et al., 2002) e ensaio imunocromatográfico (EIC) (KIM et al., 2007; WANKE et al., 2012).

Os diferentes métodos de diagnóstico sorológico variam em sensibilidade e especificidade, podendo levar a resultados falsos positivos e negativos, dependendo do estágio da doença e do antígeno utilizado (WANKE, 2004). Testes baseados em antígenos de parede celular, geralmente apresentam maior sensibilidade na detecção de cães na fase de bacteremia, dificultando o diagnóstico nas fases mais adiantadas da infecção (KEID et al., 2009). Ademais, reações cruzadas podem ser observadas com outros gêneros bacterianos, como Bordetella, Pseudomonas, Staphylococcus, Francisella, Campylobacter, Salmonella, Pasteurella e Yersinia (GEORGE; CARMICHAEL, 1974; FLORES-CASTRO; CARMICHAEL 1978; CARMICHAEL et al., 1984; CORBEL et al., 1984; CARMICHAEL; JOUBERT, 1987; BOUNAADJA et al., 2009; ARAS; UÇAN, 2010).

A SAR é uma prova sorológica que tem sido utilizada como teste de triagem das infecções por B. canis, podendo revelar anticorpos a partir de três a quatro semanas da infecção, sendo relatados valores relativamente elevados de sensibilidade (GREENE; CARMICHAEL, 2006; KEID et al., 2009). É um teste barato, rápido e de fácil realização, passível de utilização em estabelecimentos de atendimento veterinário (CARMICHAEL; SHIN, 1996). Como antígeno, usualmente é utilizada uma amostra de B. ovis corada com rosa de bengala (BADAKHSH et al., 1982; CARMICHAEL; JOUBERT, 1987), porém a especificidade deste teste pode ser baixa, resultando em uma proporção significativa de resultados falsos positivos 
(GEORGE; CARMICHAEL, 1978). Para reduzir a ocorrência de resultados falsos positivos, recomenda-se o tratamento prévio dos soros com 2-mercaptoetanol (2-ME), para desnaturação de IgM, reduzindo-se, assim, as ligações inespecíficas (JOHNSON; WALKER, 1992; CARMICHAEL; SHIN, 1996). Contudo, o emprego do 2- ME pode resultar em redução da sensibilidade, por impedir a detecção de cães nas fases iniciais da infecção, antes do desenvolvimento de títulos de IgG (KEID et al., 2009). Há relatos de que a utilização de uma amostra não mucoide de B. canis (M-) pode aumentar a especificidade do teste sem alterar sua sensibilidade (DAMP et al., 1973; CARMICHAEL; JOUBERT, 1987). Há um kit comercial baseado num ensaio de soroaglutinação rápida, porém, o mesmo não se encontra disponível no Brasil.

A SAL é um teste semiquantitativo, capaz de detectar anticorpos para B. canis em cães a partir de duas a quatro semanas após a exposição ou a bacteremia (ALTON et al., 1976). Apresenta sensibilidade mais baixa que a SAR, no entanto, sua especificidade pode ser superior, devido à possibilidade de titulação dos soros caninos (HOLLET, 2006; JOHNSON; WALKER, 1992). Na SAL, títulos de anticorpos entre 50 e 100 são considerados suspeitos, sendo recomendado o reteste após 30 dias; e títulos iguais ou superiores a 200 devem ser considerados positivos (GREENE; CARMICHAEL, 2006). Este teste, porém, tem sido pouco utilizado atualmente e não há kits comerciais disponíveis.

Para a realização da prova de imunodifusão em gel de ágar (IDGA) podem ser utilizados antígenos de parede celular bacteriana (compostos por LPS e proteínas de membrana) ou antígenos de proteínas citoplasmáticas (PC) (CARMICHAEL, 1990; GREENE; CARMICHAEL, 2006). A IDGA com utilização de antígeno de superfície bacteriana permite a detecção de anticorpos a partir de oito a 12 semanas após a infecção e apresenta menor sensibilidade em comparação à SAR, mas elevada especificidade (ZOHA; CARMICHAEL, 1982; KEID et al., 2009, 2015). A IDGA com uso de antígenos de PC é caracterizada por elevada especificidade, mas baixa sensibilidade diagnóstica especialmente na fase inicial da infecção (ZOHA; CARMICHAEL, 1982). Por outro lado, os anticorpos contra proteínas citoplasmáticas tendem a permanecer por períodos mais prolongados (até 36 meses), permitindo a identificação de animais em fase crônica da infecção, após o término da fase de bacteremia (ZOHA; CARMICHAEL, 1982; CARMICHAEL et al., 1984; CARMICHAEL; GREENE, 1990). No Brasil, há um kit de IDGA que utiliza antígenos de parede celular comercialmente disponível, porém, não há testes comerciais de IDGA baseados em antígenos citoplasmáticos. 
Ensaios imunoenzimáticos para o diagnóstico da infecção têm sido desenvolvidos, utilizando uma variedade de antígenos ( MATEU-DE-ANTONIO et al., 1993; BALDI et al., 1994, 1997; ARESE et al., 1999; LETESSON et al., 1997; BARROUIN-MELO et al., 2007; CLOECKAERT et al., 2001; WANKE et al., 2002; ZYGMUNT et al., 2002). A utilização de antígenos citoplasmáticos de Brucella tem como vantagem não apresentar reação cruzada com outras bactérias pertencentes a outros gêneros, tornando o teste altamente específico (MINHARRO et al., 2005). O teste de ELISA empregando antígeno de parede celular de $B$. canis obtido por solução salina aquecida demonstrou boa sensibilidade e especificidade (BARROUIN-MELO et al., 2007). Em termos de sensibilidade, a técnica parece ser superior aos testes de aglutinação para o diagnóstico da brucelose canina (WANKE et al., 2002).

O ELISA utilizando proteínas recombinantes de Brucella spp. como antígenos foram propostos para o diagnóstico da brucelose, com maior especificidade na detecção da infecção (ARESE et al., 1999; CLOECKAERT et al., 2001; WANKE et al., 2002; ZYGMUNT et al., 2002). Porém, a sensibilidade pode ser baixa, devido ao pequeno número de determinantes antigênicos envolvidos na ligação a anticorpos específicos quando da utilização de proteínas recombinantes (CASSATARO et al., 2002, 2004). As proteínas recombinantes CP24 (CASSATARO et al., 2002), Omp31 (Outer Membrane Protein 31) (CASSATARO et al., 2004), BP26 (ARESE et al., 1999), LS (Lumazina Sintase) (WANKE et al., 2002) e Cu-Zn superóxido dismutase (SOD) (TSOGTBAATAR et al., 2008) de Brucella spp foram utilizadas para o sorodiagnóstico da brucelose canina.

Pesquisas recentes demonstraram elevada especificidade dos ensaios imunocromatográficos desenvolvidos para o diagnóstico da brucelose canina, além de valores de sensibilidade similares ou superiores aos testes de aglutinação e imunodifusão. Apesar da elevada sensibilidade em relação aos testes de SAR e IDGA, aproximadamente $10 \%$ de resultados falsos negativos foram relatados em diferentes estudos (WANKE et al., 2012; KEID et al., 2015). Além da maior sensibilidade diagnóstica, estes testes são rápidos e de simples execução, possibilitando agilidade no diagnóstico. No Brasil, há kits comercialmente disponíveis baseados em ensaios imunocromatográficos.

Em razão dos problemas de sensibilidade e especificidade observados nos testes sorológicos aplicados ao diagnóstico da brucelose nos cães, o diagnóstico definitivo da infecção deve basear-se na associação destes com métodos diretos de diagnóstico, como o isolamento 
bacteriano e a reação em cadeia pela polimerase (PCR) (WOOLEY et al., 1978; MULLIS, 1990; MELO et al., 1997; KEID et al., 2007a,b,c).

A confirmação do diagnóstico da brucelose canina pode ser feita pelo isolamento de $B$. canis a partir de amostras de sangue, tecidos fetais, secreções vaginais, leite, sêmen, urina, próstata, baço, fígado, medula óssea e linfonodos (CARMICHAEL, 1990; WANKE, 2004; HOLLET, 2006; ARAS et al., 2010). A bactéria já foi isolada também do útero (BRENNAN et al., 2008), a partir do humor aquoso em caso de uveíte (JOHNSON; WALKER, 1992), bem como de casos de discoespondilite e osteomielite (SMEAK et al., 1987; KERWIN et al., 1992).

O material de eleição a ser coletado para o diagnóstico da brucelose canina está relacionado com a fase da infecção em que o animal se encontra. Nas fêmeas infectadas, as secreções vaginais durante o período imediatamente após abortamento constituem uma fonte predominante de Brucella, sendo útil para o diagnóstico (JOHNSON; WALKER, 1992; KEID et al., 2007a). Para os machos, o cultivo de sêmen parece apresentar maior sensibilidade nos primeiros 3 meses após a infecção, quando há eliminação de maiores quantidades bacterianas pelo sêmen. No entanto, após este período pode haver redução da sensibilidade devido à eliminação intermitente de B. canis (GEORGE et al., 1979; CARMICHAEL; GREENE, 2006; KEID et al., 2007b). Contudo, devido ao prolongado período de bacteremia característico da doença, o sangue é considerado o material de eleição para o isolamento bacteriano (JOHNSON; WALKER, 1992; CARMICHAEL; SHIN, 1996; KEID et al., 2002).

O isolamento bacteriano é um método de elevada especificidade diagnóstica, ou seja, um resultado positivo confirma a infecção, porém, um resultado negativo não exclui a possibilidade da mesma, pois sua sensibilidade depende de vários parâmetros como período da infecção e de eliminação bacteriana na amostra a ser testada, material malconservado, inviabilizando a bactéria, presença de contaminantes secundários e uso de antibióticos (MINHARRO et al., 2005; HOLLET, 2006).

Embora o isolamento bacteriano seja considerado o teste padrão-ouro para o diagnóstico da brucelose canina, o mesmo apresenta algumas dificuldades como o tempo necessário para a sua realização que pode durar no mínimo 10 dias, risco de contaminação das amostras por outras bactérias de crescimento rápido, que podem prejudicar o crescimento de Brucella no meio de cultura, risco de infecção para os laboratoristas, além da necessidade de estrutura laboratorial adequada e pessoal treinado para a manipulação e identificação das colônias bacterianas isoladas (BRICKER, 2002; WANKE, 2004). 
A PCR é uma alternativa ao isolamento bacteriano para o diagnóstico direto de brucelose canina. É uma técnica rápida, de alta especificidade e sensibilidade, capaz de detectar DNA de Brucella em pequenas quantidades, que não necessitam estar viáveis, além de permitir o processamento de amostras clínicas contaminadas (ERLICH et al., 1991; BRICKER, 2002; KEID et al., 2007a,b,c).

Assim como o isolamento bacteriano, a PCR pode ser realizada a partir de diversos tipos de amostras biológicas. Em cães, há relatos de sua utilização a partir de amostras de sangue (KEID et al., 2007c), esfregaço vaginal (KEID et al., 2007a), sêmen (KIM et al., 2006; KEID et al., 2007b) e linfonodos inguinais (ARAS; UÇAN, 2010). A PCR de $s w a b$ vaginal de cadelas apresentando descargas vaginais em estro e interestro, demonstrou ser mais sensível quando comparada com o cultivo, porém, a sensibilidade foi ainda mais elevada ao utilizar amostras de sangue (KEID et al., 2007a).

Resultados positivos foram observados na PCR a partir de amostras de sêmen de cães que não apresentavam bacteremia, indicando que esta técnica pode ser utilizada para confirmação da infecção em cães com suspeita clínica ou epidemiológica de brucelose, mas que apresentaram resultado negativo pela PCR a partir de amostra de sangue (KEID et al., 2007b).

Ao testar amostras de linfonodo inguinal de 48 cães post mortem pela PCR, valores de sensibilidade e especificidade de $100 \%$ em relação ao cultivo microbiológico foram observados. Ademais, o linfonodo inguinal se mostrou útil para o diagnóstico da brucelose canina nos casos de infecções crônicas, já que em alguns casos os animais eram assintomáticos e o cultivo microbiológico não foi possível a partir de outros tecidos (baço, fígado, linfonodos mesentéricos) (ARAS; UÇAN, 2010).

O controle e profilaxia da B. canis em populações de cães envolve alguns procedimentos como a confirmação do diagnóstico através de testes sorológicos e bacteriológicos, quarentena, identificação e eliminação dos animais infectados (JONES; EMERSON, 1984; PICKERILL; CARMICHAEL, 1972; JOHNSON; WALKER, 1992). Como não há vacina contra brucelose para cães, é importante implantar programas de prevenção. Animais recém-adquiridos devem ser isolados durante pelo menos um mês (JOHNSON; WALKER, 1992; RHOADES et al., 1980) e apresentar duas sorologias negativas em intervalo de 30 dias antes de serem introduzidos em um canil (RHOADES et al., 1980). Recomenda-se a realização de testes anuais e a remoção ou eutanásia de cães positivos (JOHNSON; WALKER, 1992). As fêmeas 
infectadas podem proporcionar ninhadas normais e transmitir a infecção para seus descendentes (HOLLET, 2006).

O contato direto com secreções ou produtos do abortamento representa risco de infecção para o homem. A manipulação dos filhotes ou fetos durante o parto ou abortamento deve ser feita com uso de luvas e roupas adequadas para garantir a segurança do tratador. $B$. canis não é capaz de sobreviver por períodos prolongados fora do organismo. Contudo, deve ser realizada a desinfecção e higienização das instalações com o uso de produtos como amônia quaternária, hipoclorito de sódio 1\%, soluções iodadas, etanol 70\% ou formaldeído (LAGE et al., 2006). O repovoamento do canil deve ser iniciado após a obtenção de pelo menos dois testes negativos com intervalo de 30 dias em todos os cães do local (HOLLETT, 2006).

O tratamento é, muitas vezes recomendado para animais de estimação e envolve castração de machos e fêmeas em combinação com a terapia antibiótica. O tratamento pode reduzir as manifestações clínicas da infecção, porém, sua eficiência em eliminar a bactéria dos tecidos do animal acometido é discutível, devido à natureza intracelular da bactéria (CARMICHAEL; GREENE, 2006; WANKE et al., 2006). Os proprietários que optam por tratar cães infectados devem realizar o monitoramento dos animais durante toda sua vida, utilizando-se testes pós-tratamento, pois a recrudescência, da infecção pode ocorrer (BRENNAN et al., 2008). Além disso, o custo do tratamento é elevado, devido à necessidade de associação de vários antimicrobianos, em doses elevadas e durante períodos prolongados (mínimo de 30 dias), de maneira que a terapia antimicrobiana é, por vezes, inviável quando um grande número de animais é acometido, sendo a eutanásia, a melhor opção para controle da infecção.

Diferente do que ocorre na brucelose bovina, não há uma legislação específica que determine medidas legais a serem tomadas em casos positivos de brucelose canina no Brasil (LAGE et al., 2006), contudo, vale ressaltar a importância desta enfermidade não só no contexto da saúde pública, por se tratar de uma zoonose, como também do ponto de vista econômico, por causar prejuízos financeiros aos criadores. Portanto, torna-se importante tomar medidas preventivas para evitar a transmissão da doença para os seres humanos, assim como para outros animais (CARMICHAEL, 1976). 


\section{JUSTIFICATIVA}

Os testes sorológicos são imprescindíveis ao diagnóstico laboratorial da brucelose animal em geral, devido ao seu baixo custo, facilidade de execução e rapidez para a obtenção dos resultados. Assim, são úteis para o diagnóstico populacional da infecção, para o monitoramento de propriedades e de regiões onde a infecção é endêmica ou como ferramenta de vigilância epidemiológica em locais onde a infecção foi erradicada. Nos animais de produção, os testes laboratoriais diretos em geral não são utilizados como métodos rotineiros de diagnóstico, mas são importantes na confirmação bacteriológica dos focos da infecção e na caracterização das estirpes de Brucella circulantes.

A brucelose canina causada pela B. canis é uma enfermidade endêmica no Brasil, com elevadas frequências de ocorrência em populações caninas de reprodutores e criadas de forma confinada, como nos canis de criação. Apesar do seu potencial zoonótico, o diagnóstico e o controle da infecção raramente são realizados por criadores de cães, em razão da baixa eficiência e alto custo dos testes laboratoriais atualmente disponíveis no Brasil, bem como pela falta de conhecimento dos mesmos sobre a importância da enfermidade.

Os testes sorológicos disponíveis para o diagnóstico da brucelose canina demonstraram valores de sensibilidade questionáveis para que possam ser aplicados como métodos únicos de diagnóstico da infecção. Baixos valores se sensibilidade foram relatados em cães durante a fase de bacteremia, mas principalmente em cães não bacterêmicos (KEID et al., 2009; WANKE et al. 2012).

A hemocultura e a PCR em amostras de sangue são métodos laboratoriais imprescindíveis ao diagnóstico da brucelose canina, permitindo a identificação de animais infectados durante o período de bacteremia, sendo marcadores capazes de identificar de forma eficiente animais nesta fase da infecção, período em que a o potencial de transmissão destes cães parecer ser alto, devido à eliminação de grandes quantidades bacterianas em secreções e excreções (KEID et al., 2007a,b). Porém, estes testes não permitem a detecção de cães infectados não bacterêmicos.

O maior problema referente ao diagnóstico da brucelose canina está relacionado à ausência de marcadores que possibilitem a identificação de cães cronicamente infectados (em ausência de bacteremia) numa população. A PCR aplicada a amostras de urina, sêmen e 
secreções vaginais pode auxiliar na detecção de cães nestas condições, contudo sua sensibilidade diagnóstica depende da eliminação bacteriana nestas secreções, que pode ocorrer de forma intermitente.

A utilização de amostras de aspirados de linfonodos pode levar a um incremento na sensibilidade dos testes diretos de diagnóstico para a detecção dos cães infectados em ausência de bacteremia, devido à disseminação das brucelas para os órgãos linfoides e persistência destas no interior de macrófagos teciduais (BYNDLOSS; TSOLIS, 2016). Amostras de aspirados de linfonodos vêm sendo utilizadas com sucesso para o diagnóstico da leishmaniose visceral canina (LOPES et al., 2017). 


\section{OBJETIVOS}

\subsection{GERAIS}

Avaliar o desempenho das técnicas de cultivo microbiológico e PCR aplicadas às amostras de aspirados de linfonodos e do ensaio imunocromatográfico nas amostras de soro de cães naturalmente infectados por B. canis.

\subsection{ESPECÍFICOS}

- Padronizar o cultivo microbiológico aplicado ao diagnóstico direto da brucelose canina em amostras de aspirado de linfonodo, utilizando dois protocolos distintos.

- Padronizar a técnica de PCR aplicada ao diagnóstico direto da brucelose canina em amostras de aspirado de linfonodo.

- Comparar o desempenho do cultivo microbiológico e da PCR em amostras de aspirados de linfonodos com o desempenho do ensaio imunocromatográfico em amostras de soro para o diagnóstico da brucelose canina em cães naturalmente infectados.

- Determinar a combinação de testes que possibilite o diagnóstico da brucelose canina com maiores valores de sensibilidade e especificidade. 


\section{MATERIAL E MÉTODOS}

\subsection{CEPAS BACTERIANAS UTILIZADAS}

A cepa de referência de Brucella canis RM6/66 (ATCC 23365; BCCN R18) foi utilizada para determinação da sensibilidade analítica da PCR em amostras de aspirados de linfonodos. A estirpe de B. canis RM6/66 foi gentilmente cedida pela Profa. Dra. Marisa da Costa, do Departamento de Microbiologia, Instituto de Ciências Básicas da Saúde, Universidade Federal do Rio Grande do Sul.

A cepa de referência de B. canis, mantida congelada em meio caldo triptose (Difco, San Diego, EUA) acrescido de 5\% de soro fetal bovino (SFB, Cultilab, Campinas, Brasil) e 25\% de glicerol à temperatura de $-80^{\circ} \mathrm{C}$, foi descongelada e semeada em placas contendo ágar triptose (Difco). As placas foram incubadas em aerobiose durante 72 horas. Após o crescimento bacteriano, a confirmação de pureza das colônias foi realizada por meio da coloração de Gram e em seguida as colônias isoladas foram submetidas à extração de DNA utilizando-se protocolo baseado em lise enzimática e purificação com solventes orgânicos (SAMBROOK; FRITSCH; MANIATIS; 1989; WILSON 1990).

\subsection{ANIMAIS}

Foram utilizados 92 cães sem distinção de raça, idade ou sexo, mediante consentimento e autorização dos proprietários, compreendendo: 69 cães provenientes de três canis comerciais nos quais foram verificados histórico de problemas reprodutivos como abortamentos, ocorrência de natimortos e falhas de concepção, cinco cães não reprodutores, porém, com suspeita clínica ou epidemiológica da infecção, 13 cães não reprodutores e sem suspeita clínica de brucelose e cinco cães reprodutores provenientes de um canil considerado livre da infecção por B. canis.

Todos os animais foram submetidos à anamnese e avaliação clínica para determinação da presença de pelo menos um dos sinais clínicos sugestivos para brucelose: secreção vaginal fora do período de estro ou pós-parto, abortamento, ocorrência de natimortos, nascimento de filhotes fracos, orquite, epididimite, falha de concepção e aumento do volume de linfonodos 
mandibulares e poplíteos. Foram considerados os sinais clínicos observados no momento da colheita ou em período precedente de dois anos.

Todos os cães tiveram amostras de sangue previamente testadas por Batinga (2017), utilizando-se os testes de hemocultura e PCR em amostras de sangue baseado em primers direcionados à sequência de inserção 711 (IS711) de Brucella, sendo que dos 92 cães, 37 foram positivos pelos testes de hemocultura e/ou PCR aplicada em amostras de sangue (grupo de cães infectados) e 55 foram negativos pelo cultivo microbiológico e pela PCR em amostras de sangue (grupo de cães não infectados).

O projeto foi aprovado pelo Comitê de Ética em Pesquisa da Faculdade de Medicina Veterinária e Zootecnia da Universidade de São Paulo (CEUA/FMVZ/USP), sob o número de protocolo 1534060215.

\subsection{AMOSTRAS BIOLÓGICAS}

As amostras biológicas foram colhidas utilizando materiais estéreis e de forma asséptica, sendo realizada tricotomia no local a ser puncionado e, em seguida, desinfecção com algodão embebido em álcool $70^{\circ}$.

\subsubsection{Soro}

Amostras de sangue foram colhidas através de punção intravenosa das veias cefálica ou jugular dos cães, realizada de forma asséptica utilizando tubos a vácuo estéreis. As amostras de soro foram obtidas por meio de centrifugação a 2000 x g durante 10 minutos para separação do coágulo sanguíneo e mantidas congeladas a $-20^{\circ} \mathrm{C}$ até as análises.

\subsubsection{Aspirado de Linfonodo}

De cada animal foi colhido conteúdo linfático através de punção aspirativa dos linfonodos poplíteos. O conteúdo aspirado foi ressuspendido em $500 \mu \mathrm{L}$ de solução de $\mathrm{NaCl}$ a $0,9 \%$ estéril e mantido sob refrigeração durante o transporte para o laboratório. Uma parte do volume foi utilizado para cultivo microbiológico empregando dois protocolos distintos e o restante foi estocado a $-20^{\circ} \mathrm{C}$ para realização da PCR. 


\subsection{CULTIVO MICROBIOLÓGICO DAS AMOSTRAS DE ASPIRADOS DE LINFONODOS}

O cultivo microbiológico de B. canis a partir de amostras de aspirados de linfonodos foi realizado no Laboratório de Doenças Parasitárias do Departamento de Medicina Veterinária Preventiva e Saúde Animal (VPS) da Faculdade de Medicina Veterinária e Zootecnia (FMVZ), Universidade de São Paulo (USP), campus de Pirassununga-SP.

\subsubsection{Cultivo Microbiológico Direto}

As amostras de aspirado de linfonodo colhidas em solução de $\mathrm{NaCl}$ a $0,9 \%$ foram semeadas, num volume de $100 \mu \mathrm{L}$, diretamente em placas contendo ágar triptose (Difco), suplementado com 5\% de SFB (Cultilab). As placas foram incubadas em aerobiose a $37^{\circ} \mathrm{C}$ durante 15 dias. Após este período, realizou-se a identificação das colônias isoladas.

\subsubsection{Cultivo Microbiológico com Enriquecimento em Meio Líquido (caldo)}

Para o isolamento bacteriano, foram semeados $100 \mu \mathrm{L}$ da suspensão de aspirados de linfonodos colhidas em $\mathrm{NaCl}$ 0,9\% em tubos estéreis contendo $10 \mathrm{~mL}$ de caldo triptose (Difco), com $5 \%$ de SFB (Cultilab) e incubados em aerobiose a $37^{\circ} \mathrm{C}$ durante 30 dias (ALTON, et al. 1976). A cada cinco dias foram realizados subcultivos em placas contendo ágar triptose (Difco), suplementado com 5\% de SFB (Cultilab), as quais foram incubadas a $37^{\circ} \mathrm{C}$, em aerobiose durante sete dias. As colônias isoladas foram posteriormente identificadas.

\subsubsection{Identificação Bacteriana}

A identificação bacteriana foi baseada em características morfológicas das colônias isoladas, sendo considerados a forma e o aspecto, além de suas características tintoriais pela coloração de Gram e microscopia óptica, com objetiva de 1000x (ALTON et al., 1976). As colônias bacterianas com características morfológicas e tintoriais sugestivas de brucelose foram submetias ao procedimento de extração de ácidos nucleicos e posterior identificação molecular (BATINGA, 2017). 


\subsection{EXTRAÇÃO DE ÁCIDOS NUCLEICOS}

A extração de DNA bacteriano foi realizada a partir da cepa de referência de $B$. canis para determinação da sensibilidade analítica da PCR e a partir das colônias bacterianas isoladas das amostras de aspirados de linfonodos caninos que apresentaram morfologia sugestivas do gênero Brucella, para identificação bacteriana. Também foi realizada a extração de DNA a partir das amostras de aspirados de linfonodos obtidos dos cães.

Estes procedimentos foram realizados no Laboratório de Doenças Parasitárias do VPS da FMVZ, USP, campus de Pirassununga-SP.

\subsubsection{Extração de Ácidos Nucleicos da Cepa de Referência de B. canis}

As colônias bacterianas foram coletadas das placas utilizando-se alças bacteriológicas descartáveis e estéreis e ressuspendidas em $500 \mu \mathrm{l}$ de tampão de lise composto por $10 \mathrm{mM}$ de Tris-HCl; $25 \mathrm{mM}$ de EDTA; $100 \mathrm{mM}$ de $\mathrm{NaCl} ; 1 \%$ de SDS e $0,8 \mathrm{mg} / \mathrm{ml}$ de proteinase K. Após homogeneização, as amostras foram incubadas em termobloco a $37^{\circ} \mathrm{C}$, overnight e em seguida purificadas utilizando-se protocolo padrão baseado na utilização de solução de brometo de hexadeciltrimetilamonio $(\mathrm{CTAB}) / \mathrm{NaCl}$ e solventes orgânicos (fenol:clorofórmio) (SAMBROOK; FRITSCH; MANIATIS; 1989; WILSON 1990). O DNA extraído foi acondicionado a $-20^{\circ} \mathrm{C}$ até a realização das reações de amplificação.

\subsubsection{Extração de Ácidos Nucleicos das Colônias Bacterianas Isoladas de Aspirados de Linfonodos Caninos}

Com o auxílio de alças bacteriológicas descartáveis e estéreis, uma amostra de cada colônia previamente selecionada foi colhida e ressuspendida em $300 \mu \mathrm{L}$ de solução TE $(10 \mathrm{mM}$ de Tris-HCl, pH 8.0, e 1 mM de EDTA, pH 8.0). Em seguida, a extração de ácidos nucleicos das colônias bacterianas foi realizada por meio de fervura em termobloco aquecido a $99^{\circ} \mathrm{C}$ durante 30 minutos. As amostras foram mantidas congeladas a $-20^{\circ} \mathrm{C}$ até a realização das reações de amplificação de ácidos nucléicos. 


\subsubsection{Extração de Ácidos Nucleicos das Amostras de Aspirado de Linfonodos}

A extração de ácidos nucleicos das amostras de aspirado de linfonodos foi realizada conforme o protocolo descrito a seguir, baseado no método de extração de DNA de amostras de sangue canino descrito por Batinga et al. (2017):

- Descongelar amostras de aspirados de linfonodos coletadas em $500 \mu \mathrm{L}$ de solução de $\mathrm{NaCl}$ a $0,9 \%$ estéril;

- Transferir $200 \mu \mathrm{L}$ da amostra para um microtubo contendo $0,1 \mathrm{~g}$ de pérolas de zircônia de $1 \mathrm{~mm}$ e $0,2 \mathrm{~g}$ de pérolas de sílica de $0,1 \mathrm{~mm}$ e adicionar $50 \mu \mathrm{L}$ de tampão de pré-lise $(20$ $\mathrm{mM}$ de Tris- $\mathrm{HCl}, 2 \mathrm{mM}$ de EDTA, 1,2\% de Triton X-100 e $20 \mathrm{mg} / \mathrm{mL}$ de lisozima);

- Homogeneizar em TissueLyser (Qiagen, Hilden, Germany) a 50 Hz, durante 5 min;

- Incubar a $37^{\circ} \mathrm{C}$ durante 2 horas, homogeneizando em TissueLyser (Qiagen) a $50 \mathrm{~Hz}$, durante 5 min, 2 vezes durante a incubação;

- Centrifugar as amostras em spin;

- Acrescentar $250 \mu \mathrm{L}$ do tampão de lise (1\% de SDS, $10 \mathrm{mM}$ de Tris-HCl, pH 8,0, $25 \mathrm{mM}$ de EDTA e $0,8 \mathrm{mg} / \mathrm{mL}$ de proteinase $\mathrm{K}$ );

- Homogeneizar em TissueLyser (Qiagen), a $50 \mathrm{~Hz}$, durante $5 \mathrm{~min}$;

- Incubar a $37^{\circ} \mathrm{C}$ overnight, homogeneizando em TissueLyser (Qiagen), a $50 \mathrm{~Hz}$, durante 5 min, 5 vezes durante a incubação;

- Centrifugar em spin;

- Transferir $420 \mu \mathrm{L}$ do lisado (exceto pérolas de sílica e zircônia) para novo microtubo.

- $\quad$ Acrescentar $500 \mu \mathrm{L}$ de fenol:clorofórmio (1:1);

- Homogeneizar em vórtex;

- Centrifugar a 13.000 x g durante 5 minutos, a $8^{\circ} \mathrm{C}$;

- Transferir $400 \mu \mathrm{L}$ do sobrenadante (fase aquosa) para novo microtubo;

- Acrescentar $400 \mu \mathrm{L}$ de clorofórmio;

- Homogeneizar em vórtex;

- Centrifugar a $13.000 \mathrm{x}$ g durante 5 minutos, a $8^{\circ} \mathrm{C}$;

- Transferir $300 \mu \mathrm{L}$ do sobrenadante (fase aquosa) para novo microtubo;

- Acrescentar $300 \mu \mathrm{L}$ de propanol e $12,5 \mu \mathrm{L}$ de $\mathrm{NaCl}$ a $5 \mathrm{M}$;

- Homogeneizar por inversão;

- Incubar em freezer a $-20^{\circ} \mathrm{C}$ durante 30 minutos; 
- Centrifugar a 13.000 x g durante 30 minutos, a $8^{\circ} \mathrm{C}$;

- Descartar o sobrenadante;

- Acrescentar $1 \mathrm{~mL}$ de etanol 70\%;

- Centrifugar a $13.000 \mathrm{x}$ g durante 30 minutos, a $8^{\circ} \mathrm{C}$;

- Descartar o sobrenadante;

- Secar o sedimento de DNA em termobloco a $56^{\circ} \mathrm{C}$;

- Acrescentar $30 \mu \mathrm{L}$ de tampão TE (1 mM de Tris-HCl, pH 8,0 e 10 mM de EDTA);

- Incubar a $56^{\circ} \mathrm{C}$ durante 30 minutos.

As amostras de DNA extraídas foram congeladas a $-20^{\circ} \mathrm{C}$ até a realização da reação de amplificação.

A cada processo de extração, foi incluído um controle negativo para cada duas amostras de aspirado de linfonodo canino, compreendendo $200 \mu \mathrm{L}$ de água ultrapura, o qual foi submetido aos mesmos procedimentos de lise, purificação, precipitação e amplificação de DNA, com o objetivo de garantir a qualidade dos reagentes utilizados bem como a ausência de contaminação cruzada de amostras durante o procedimento.

\subsection{QUANTIFICAÇÃO DE DNA E PREPARO DAS DILUIÇÕES SERIADAS DE DNA DE BRUCELLA CANIS}

A amostra de DNA obtida a partir da cepa de B. canis RM6/66, conforme descrito no item 4.5.1 foi submetida à leitura em espectrofotômetro DS-11 FX (DeNovix Inc., USA), obtendo-se os seguintes valores: concentração de DNA de 1,346 ng/ $\mu 1$, sendo a razão 260/280 de 1,9 e o valor de absorbância a $260 \mathrm{~nm}$ de 0,26.

Em seguida, foram preparadas duas séries de diluições na base dez da amostra de DNA obtida de $B$. canis, previamente quantificada. Uma das séries foi diluída em tampão TE e a segunda série foi diluída em DNA obtido a partir de aspirado de linfonodo canino, com a finalidade de verificar a possível interferência do DNA canino na reação de amplificação.

Para este procedimento, foram utilizadas amostras de DNA de aspirados de linfonodos extraídas (conforme item 4.5.3) de quatro cães não infectados, procedentes de canil livre de brucelose. As quatro amostras de DNA canino obtidas foram quantificadas em espectrofotômetro DS-11 FX (DeNovix), sendo verificadas as seguintes concentrações de DNA 
para cada uma delas: 17,39 ng/ $\mu \mathrm{l}$ (razão 260/280 de 1,29 e absorbância a $260 \mathrm{~nm}$ de 0,34); 7,71

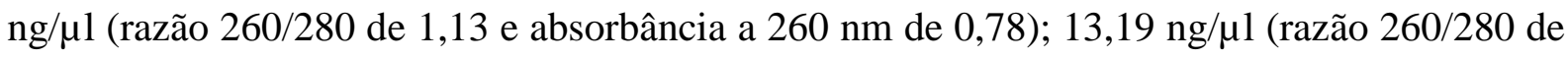


$\mathrm{nm}$ de 0,48$)$. Em seguida, foi preparado um pool contendo as quatro amostras de DNA obtido de aspirados de linfonodos caninos, o qual foi utilizado como diluente para preparo da segunda série de diluição do DNA de B. canis.

Assim, foram obtidas as seguintes concentrações de DNA de B. canis, em tampão TE e em DNA obtido de aspirado de linfonodo canino: 134,6 pg/ $\mu 1,13,4 \mathrm{pg} / \mu 1,1,34 \mathrm{pg} / \mu 1,134,6$ $\mathrm{fg} / \mu 1,13,46 \mathrm{fg} / \mu 1,1,346 \mathrm{fg} / \mu 1,0,1346 \mathrm{fg} / \mu 1$ (Figura 1).

As amostras foram mantidas a $-20^{\circ} \mathrm{C}$ até a realização das reações de amplificação de DNA para determinação da sensibilidade analítica da PCR para detecção de B. canis, tanto na presença quanto na ausência de DNA canino.

Figura 1. Diluição da amostra de DNA de Brucella canis em solução TE ou em amostras de DNA canino a partir de cães negativos para Brucella sp..

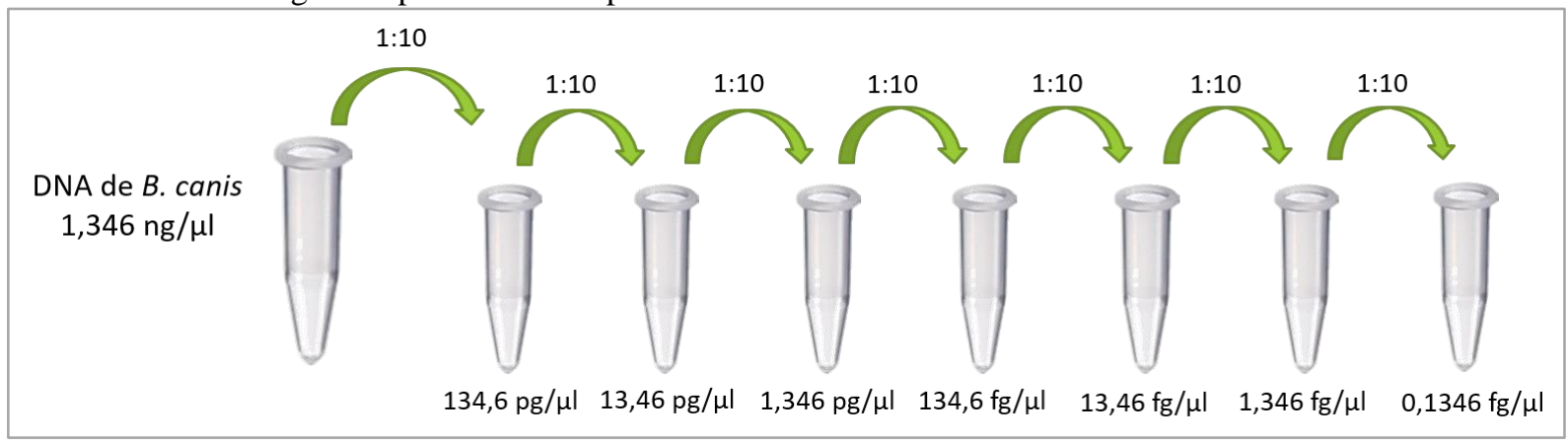

\subsection{REAÇÃO EM CADEIA PELA POLIMERASE (PCR)}

A PCR foi realizada nas amostras de DNA da cepa de referência de B. canis, diluída em tampão TE e em DNA canino, para determinação da sensibilidade analítica da reação, nas amostras de DNA extraído das colônias bacterianas isoladas a partir das amostras de aspirados de linfonodos caninos para identificação bacteriana e nas amostras de DNA extraído diretamente de aspirados de linfonodos caninos.

Para detecção de Brucella sp, foram utilizados primers desenhados por Batinga (2017), direcionados à sequência de inserção 711 (IS711), que é considerada específica do gênero Brucella, os quais amplificam um fragmento de 262 pares de base (pb). A sequência dos primers pode ser visualizada no quadro 1. 
Quadro 1. Sequência dos primers direcionados à sequência de inserção 711 (IS711) utilizados para detecção de Brucella spp. pela reação em cadeia pela polimerase.

\begin{tabular}{cc}
\hline Primers & Sequência \\
\hline IS517 F22 & 5'TGTCCGCAAGCTTCAAGCCTTC 3' \\
\hline IS755 R24 & 5'CGGTCAATGTTTTCTCGCATCGCA 3' \\
\hline
\end{tabular}

Para as reações de amplificação, um volume de $5 \mu \mathrm{L}$ de DNA foi misturado a $45 \mu \mathrm{L}$ da solução de amplificação, obtendo-se as seguintes concentrações finais: tampão de reação 1x (50 $\mathrm{mM} \mathrm{KCl,} 20$ mM Tris-HCl, pH 8,4), $200 \mu \mathrm{M}$ de cada desoxirribonucleotídeo trifosfato (dATP, dCTP, dGTP, dTTP), 0,6 $\mu \mathrm{M}$ de cada primer, 1,5 mM de $\mathrm{MgCl}_{2}$, 1,5 U de Platinum Taq DNA Polymerase (Invitrogen, Carlsbad, EUA). As amplificações foram realizadas em termociclador Veriti ${ }^{\mathrm{TM}}$ Thermal Cycler (Thermo Fisher Scientific, Applied Biosystems, Waltham, EUA), sendo empregadas as seguintes condições de amplificação: desnaturação inicial à $94^{\circ} \mathrm{C}$ durante 2 minutos, seguida por 40 ciclos de desnaturação a $94^{\circ} \mathrm{C}$ durante 40 segundos, annealing a $59^{\circ} \mathrm{C}$ durante 40 segundos e extensão a $72^{\circ} \mathrm{C}$ durante 40 segundos. Uma extensão final a $72^{\circ} \mathrm{C}$ durante 10 minutos foi realizada posteriormente (BATINGA, 2017).

A cada procedimento de amplificação foram incluídos um controle negativo ( $5 \mu \mathrm{L}$ de água ultrapura) e um controle positivo de amplificação ( $5 \mu \mathrm{L}$ de DNA da cepa de referência RM6/66 de B. canis), para garantir a qualidade dos reagentes utilizados no procedimento de amplificação.

\subsection{VISUALIZAÇÃO DOS PRODUTOS AMPLIFICADOS}

A visualização dos produtos amplificados na PCR foi realizada através de eletroforese em gel de agarose (2,0\%), realizada em cuba horizontal com tampão de corrida TBE $1 \mathrm{X}(0,045$ M Tris-borato e 1 mM EDTA, pH 8,0), sendo o gel submetido a uma voltagem constante de 6$7 \mathrm{~V} / \mathrm{cm}$. A visualização das bandas foi feita após coloração do gel em solução de brometo de etídeo a $0,5 \mu \mathrm{g} / \mathrm{mL}$, durante 60 minutos e observação em transiluminador ultravioleta (SAMBROOK; FRITSCH; MANIATIS, 1989). Os produtos amplificados foram comparados ao padrão de peso molecular com fragmentos múltiplos de 100 pb. 


\subsection{ENSAIO IMUNOCROMATOGRÁFICO (EIC)}

O teste rápido baseado em ensaio imunocromatográfico Rapid Canine Brucella Ab Test Kit (Bionote, Suwon-si, South Korea) foi empregado para detecção de IgG contra B. canis nos soros dos cães amostrados. O teste emprega LPS-rugoso de Brucella ovis como antígeno e foi realizado e interpretado de acordo com as recomendações do laboratório fabricante.

\subsection{ANÁLISE DE SENSIBILIDADE E ESPECIFICIDADE DIAGNÓSTICA DOS TESTES REALIZADOS}

O padrão ouro foi definido considerando-se resultados obtidos pelo cultivo microbiológico ou pela PCR em amostras de sangue, em estudo previamente realizado (BATINGA, 2017), sendo utilizado para calcular a sensibilidade e a especificidade diagnósticas dos testes de cultivo microbiológico e PCR aplicada às amostras de aspirados de linfonodos e do EIC nas amostras de soro dos cães, conforme o modelo a seguir:

\begin{tabular}{c|c|c|c} 
& Infectados & Não infectados & Total \\
\hline Teste positivo & $\mathrm{a}$ & $\mathrm{b}$ & $(\mathrm{a}+\mathrm{b})$ \\
\hline Teste negativo & $\mathrm{c}$ & $\mathrm{d}$ & $(\mathrm{c}+\mathrm{d})$ \\
\hline Total & $(\mathrm{a}+\mathrm{c})$ & $(\mathrm{b}+\mathrm{d})$ & $\mathrm{N}$
\end{tabular}

Sensibilidade $=a /(a+c) \quad$ Especificidade $=d /(b+d)$

Assim, o cálculo da sensibilidade diagnóstica foi realizado considerando-se como infectados os 37 cães que apresentaram resultados positivos na hemocultura e/ou PCR aplicada a amostras de sangue (grupo de cães infectados) e o cálculo da especificidade diagnóstica foi realizado utilizando-se 55 cães negativos pelo cultivo microbiológico e pela PCR em amostras de sangue (grupo de cães não infectados) (PETRIE; WATSON, 1999). 


\subsection{ANÁLISE DE CONCORDÂNCIA DAS PROVAS DE DIAGNÓSTICO}

As provas de diagnóstico realizadas neste trabalho, assim como a hemocultura e a PCR em amostras de sangue foram comparadas, duas a duas, empregando-se o indicador Kappa (COHEN, 1960), com auxílio do programa SPSS 9.0.

As comparações foram realizadas considerando-se os resultados obtidos em cada técnica separadamente, bem como os resultados obtidos em diversas combinações de técnicas. 


\section{RESULTADOS}

\subsection{SENSIBILIDADE ANALÍTICA DA PCR UTILIZANDO OS PRIMERS IS711 EM AMOSTRAS DE ASPIRADO DE LINFONODO}

A PCR empregando os primers direcionados à IS711 foi capaz de detectar igualmente até $134,6 \mathrm{fg} / \mu 1$ de DNA de B. canis, diluído em tampão TE ou em amostras de DNA canino obtidas de aspirados de linfonodos.

\subsection{PROPORÇÃO DE RESULTADOS POSITIVOS PELOS MÉTODOS DE DIAGNÓSTICO EMPREGADOS NESTE TRABALHO}

Das 92 amostras de aspirados de linfonodos submetidas ao cultivo microbiológico, duas apresentaram contaminação secundária durante a incubação no caldo para enriquecimento, inviabilizando o isolamento de Brucella. Ambas as amostras foram positivas no cultivo microbiológico direto. Estas amostras foram classificadas como negativas para a realização das análises estatísticas neste trabalho.

Os isolados bacterianos caracterizados como Brucella apresentaram as seguintes caraterísticas: colônias bacterianas de 1 a $2 \mathrm{~mm}$ de diâmetro, convexas, coloração mel, translúcidas e claras, na forma de cocobastonetes pequenos e fracamente Gram negativos e resultado positivo na PCR utilizando primers direcionados à IS711.

As proporções de resultados positivos obtidos nos diferentes métodos de diagnóstico utilizados neste trabalho estão apresentadas na tabela 1.

\subsection{CONCORDÂNCIA ENTRE OS TESTES LABORATORIAIS UTILIZADOS}

A concordância entres os testes laboratoriais e suas combinações, comparados dois a dois, determinada pelo coeficiente Kappa podem ser observadas na Tabela 2. 
Tabela 1. Proporção de resultados positivos obtidos pelos testes laboratoriais diretos utilizados em amostras de sangue, pela reação em cadeia pela polimerase (PCR), cultivo microbiológico direto e cultivo microbiológico com enriquecimento em caldo nas amostras de aspirado de linfonodo e pelo ensaio imunocromatográfico (EIC) em amostras de soros dos cães examinados e suas combinações, para o diagnóstico da brucelose canina.

\begin{tabular}{|c|c|c|c|c|c|c|c|c|c|c|}
\hline $\begin{array}{c}\text { Testes } \\
\text { diretos } \\
\text { sangue }^{\mathrm{a}}\end{array}$ & $\begin{array}{c}\text { PCR } \\
\text { linfonodo }\end{array}$ & $\begin{array}{c}\text { Cultivo } \\
\text { direto } \\
\text { linfonodo } \\
\end{array}$ & $\begin{array}{c}\text { Cultivo em } \\
\text { caldo } \\
\text { linfonodo } \\
\end{array}$ & $\begin{array}{c}\text { Cultivo } \\
\text { geral } \\
\text { linfonodo }^{\mathrm{b}} \\
\end{array}$ & $\begin{array}{c}\text { Cultivo e/ou } \\
\text { PCR } \\
\text { linfonodo }^{c} \\
\end{array}$ & $\begin{array}{c}\text { Testes } \\
\text { diretos }^{\mathrm{d}}\end{array}$ & EIC & $\begin{array}{c}\text { EIC e/ou } \\
\text { testes diretos } \\
\text { sangue }^{\mathrm{e}} \\
\end{array}$ & $\begin{array}{c}\text { EIC e/ou testes } \\
\text { diretos } \\
\text { linfonodo }^{\text {f }}\end{array}$ & $\begin{array}{c}\text { Todos os } \\
\text { testes }^{\mathrm{g}}\end{array}$ \\
\hline $\begin{array}{l}40,2 \% \\
(37 / 92)\end{array}$ & $\begin{array}{c}29 \% \\
(27 / 92)\end{array}$ & $\begin{array}{c}25 \% \\
(23 / 92)\end{array}$ & $\begin{array}{c}20,6 \% \\
(19 / 92)\end{array}$ & $\begin{array}{c}25 \% \\
(23 / 92)\end{array}$ & $\begin{array}{l}31,5 \% \\
(29 / 92)\end{array}$ & $\begin{array}{c}43,4 \% \\
(40 / 92)\end{array}$ & $\begin{array}{c}43 \% \\
(40 / 92)\end{array}$ & $\begin{array}{l}46,7 \% \\
(43 / 92)\end{array}$ & $\begin{array}{c}47,8 \% \\
(44 / 92)\end{array}$ & $\begin{array}{l}48,9 \% \\
(45 / 92)\end{array}$ \\
\hline
\end{tabular}

${ }^{a}$ Foram considerados como positivos os cães que apresentaram resultado positivo em pelo menos um dos métodos diretos de diagnóstico aplicados às amostras de sangue (hemocultura ou PCR)

${ }^{\mathrm{b}}$ Foram considerados como positivos no cultivo geral os cães que apresentaram isolamento de $B$. canis em pelo menos um dos métodos de cultivo em aspirado de linfonodo

${ }^{\mathrm{c}}$ Foram considerados como positivos os cães que apresentaram resultado positivo em pelo menos um dos métodos diretos de diagnóstico aplicados às amostra de aspirados de linfonodos (cultivo microbiológico direto, cultivo microbiológico em caldo ou PCR)

${ }^{\mathrm{d}}$ Foram consideradas como positivos os cães que apresentaram resultado positivo em pelo menos um dos métodos diretos de diagnóstico aplicado às amostra de aspirados de linfonodos ou sangue (cultivo microbiológico ou PCR)

e Foram considerados como positivos os cães que apresentaram resultado positivo em pelo menos um dos métodos diretos de diagnóstico aplicados às amostra de sangue (hemocultura e PCR) e/ou no EIC.

${ }^{\mathrm{f}}$ Foram considerados como positivos os cães que apresentaram resultado positivo em pelo menos um dos métodos diretos de diagnóstico aplicados às amostra de aspirados de linfonodos (cultivo microbiológico direto, cultivo microbiológico em caldo ou PCR) e/ou no EIC.

${ }^{\mathrm{g}}$ Foram considerados como positivos os cães que apresentaram resultado positivo em pelo menos um dos testes laboratoriais utilizados (testes de diagnóstico direto em sangue, testes de diagnóstico direto em aspirados de linfonodos ou EIC). 
Tabela 2. Comparação dos resultados obtidos com o cultivo microbiológico direto, cultivo em caldo e reação em cadeia pela polimerase (PCR) em amostras de aspirados de linfonodos, hemocultura e/ou PCR em amostras de sangue e ensaio sorológico imunocromatográfico (EIC), analisados pelo coeficiente Kappa, separadamente e em combinações, para o diagnóstico da brucelose canina em 92 cães.

\begin{tabular}{|c|c|c|c|c|c|c|c|}
\hline & Resultados & & & & Kappa & & \\
\hline Teste 1 & Teste 2 & $\begin{array}{c}\text { Positivo no } \\
\text { teste } 1 \\
\text { e } \\
\text { positivo no } \\
\text { teste } 2\end{array}$ & $\begin{array}{c}\text { Negativo no } \\
\text { teste } 1 \\
\text { e } \\
\text { negativo no } \\
\text { teste } 2\end{array}$ & $\begin{array}{c}\text { Positivo no } \\
\text { teste } 1 \\
\text { e } \\
\text { negativo no } \\
\text { teste } 2\end{array}$ & $\begin{array}{c}\text { Negativo no } \\
\text { teste } 1 \\
e \\
\text { positivo no } \\
\text { teste } 2\end{array}$ & Valor & Concordância \\
\hline Cultivo linfonodo caldo & Cultivo linfonodo direto & 19 & 69 & 0 & 4 & 0,99 & Quase perfeita \\
\hline Cultivo linfonodo caldo & PCR linfonodo & 18 & 64 & 1 & 9 & 0,87 & Substancial \\
\hline Cultivo linfonodo caldo & PCR e/ou cultivo sangue & 19 & 55 & 0 & 18 & 0,72 & Moderado \\
\hline Cultivo linfonodo caldo & EIC & 18 & 51 & 1 & 22 & 0,62 & Moderado \\
\hline Cultivo linfonodo direto & PCR linfonodo & 21 & 63 & 2 & 6 & 0,92 & Substancial \\
\hline Cultivo linfonodo direto & PCR e/ou cultivo sangue & 23 & 55 & 0 & 14 & 0,81 & Substancial \\
\hline Cultivo linfonodo caldo & Hemocultura & 18 & 58 & 1 & 15 & 0,75 & Moderado \\
\hline Cultivo linfonodo direto & Hemocultura & 22 & 58 & 1 & 11 & 0,85 & Substancial \\
\hline Cultivo linfonodo direto & EIC & 22 & 51 & 1 & 18 & 0,72 & Moderado \\
\hline Cultivo linfonodo direto e/ou caldo & PCR linfonodo & 21 & 63 & 2 & 6 & 0,92 & Substancial \\
\hline Cultivo e/ou PCR linfonodo & PCR e/ou cultivo sangue & 26 & 52 & 3 & 11 & 0,82 & Substancial \\
\hline Cultivo e/ou PCR linfonodo & EIC & 25 & 48 & 4 & 15 & 0,73 & Moderado \\
\hline EIC & PCR e/ou cultivo sangue & 34 & 49 & 6 & 4 & 0,92 & Substancial \\
\hline EIC e/ou testes diretos linfonodo & PCR e/ou cultivo sangue & 37 & 48 & 7 & 0 & 0,95 & Quase perfeita \\
\hline
\end{tabular}




\subsection{SENSIBILIDADE E ESPECIFICIDADE DIAGNÓSTICA DOS TESTES REALIZADOS}

Para determinar a sensibilidade e especificidade diagnóstica dos testes de PCR, cultivo microbiológico direto e cultivo microbiológico com enriquecimento em caldo nas amostras de aspirado de linfonodos, a comparação com o padrão ouro foi realizada considerando-se cinco situações distintas:

- Situação 1: foram considerados como positivos apenas cães com reação positiva na PCR em aspirados de linfonodos.

- Situação 2: foram considerados como positivos apenas cães com isolamento de Brucella no cultivo microbiológico utilizando o protocolo de cultivo direto em ágar.

- Situação 3: foram considerados como positivos apenas cães com isolamento de Brucella no cultivo microbiológico utilizando o protocolo de enriquecimento em caldo.

- Situação 4: foram considerados como positivos cães com isolamento de Brucella em amostras de aspirados de linfonodos utilizando qualquer um dos protocolos de cultivo microbiológico empregados.

- Situação 5: foram considerados como positivos cães reagentes em pelo menos um dos testes diretos (cultivo microbiológico e PCR) aplicados às amostras de aspirados de linfonodos.

Nas tabelas de 3 a 7 são apresentados os valores de sensibilidade e especificidade diagnóstica dos testes de cultivo microbiológico e PCR aplicados às amostras de aspirados de linfonodos, nas cinco situações distintas consideradas.

Tabela 3. Sensibilidade e especificidade diagnóstica da PCR aplicada em amostras de aspirados de linfonodos caninos para diagnóstico de infecção por Brucella canis (situação 1).

\begin{tabular}{|c|c|c|c|}
\hline & Cães Infectados a & Cães não infectados ${ }^{\text {b }}$ & Total \\
\hline $\begin{array}{l}\text { Positivo na PCR em } \\
\text { aspirados de linfonodos }\end{array}$ & 24 & 3 & 27 \\
\hline $\begin{array}{l}\text { Negativo na PCR em } \\
\text { aspirados de linfonodos }\end{array}$ & 13 & 52 & 65 \\
\hline Total & 37 & 55 & 92 \\
\hline
\end{tabular}

${ }^{a}$ Cães infectados: cães com detecção de B. canis em amostras de sangue nos testes de hemocultura e/ou PCR

${ }^{\mathrm{b}}$ Cães não infectados: cães com resultados negativos na hemocultura e na PCR aplicada em amostras de sangue para detecção de B. canis.

Sensibilidade diagnóstica PCR em aspirados de linfonodos: $65 \%$

Especificidade diagnóstica PCR em aspirados de linfonodos: 95\% 
Tabela 4. Sensibilidade e especificidade diagnóstica do cultivo microbiológico para isolamento de Brucella canis em amostras de aspirados de linfonodos caninos, utilizando-se protocolo de cultivo direto em ágar (situação 2).

\begin{tabular}{llll}
\hline & Cães Infectados & a & Cães não infectados \\
& b & Total \\
\hline $\begin{array}{l}\text { Positivo no cultivo direto de } \\
\text { aspirados de linfonodos }\end{array}$ & 23 & 0 & 23 \\
$\begin{array}{l}\text { Negativo no cultivo direto } \\
\text { de aspirados de linfonodos }\end{array}$ & 14 & 55 & 69 \\
\hline Total & 37 & 55 & 92 \\
\hline
\end{tabular}

${ }^{a}$ Cães infectados: cães com detecção de B. canis em amostras de sangue nos testes de hemocultura e/ou PCR.

${ }^{\text {b }}$ Cães não infectados: cães com resultados negativos na hemocultura e na PCR aplicada em amostras de sangue para detecção de B. canis.

Sensibilidade diagnóstica do cultivo direto de aspirados de linfonodos: $62 \%$

Especificidade diagnóstica do cultivo direto de aspirados de linfonodos: 100\%

Tabela 5. Sensibilidade e especificidade diagnóstica do cultivo microbiológico para isolamento de Brucella canis em amostras de aspirados de linfonodos caninos, utilizando-se protocolo de enriquecimento em caldo (situação 3).

\begin{tabular}{llll}
\hline & Cães Infectados $^{\text {a }}$ & Cães não infectados $^{\mathbf{b}}$ & Total \\
\hline $\begin{array}{l}\text { Positivo no cultivo em caldo } \\
\text { de aspirados de linfonodos }\end{array}$ & 19 & 0 & 19 \\
$\begin{array}{l}\text { Negativo no cultivo em } \\
\text { caldo de aspirados de }\end{array}$ & 18 & 55 & 73 \\
linfonodos & & & 92 \\
\hline Total & 37 & 55 & 92 \\
\hline
\end{tabular}

${ }^{a}$ Cães infectados: cães com detecção de B. canis em amostras de sangue nos testes de hemocultura e/ou PCR.

${ }^{\text {b }}$ Cães não infectados: cães com resultados negativos na hemocultura e na PCR aplicada em amostras de sangue para detecção de B. canis.

Sensibilidade diagnóstica do cultivo em caldo de aspirados de linfonodos: $51 \%$

Especificidade diagnóstica do cultivo em caldo de aspirados de linfonodos: $100 \%$

Tabela 6. Sensibilidade e especificidade diagnóstica do cultivo microbiológico geral para isolamento de Brucella canis em amostras de aspirados de linfonodos caninos (situação 4).

\begin{tabular}{llll}
\hline & Cães Infectados $^{\text {a }}$ & Cães não infectados $^{\text {b }}$ & Total \\
\hline $\begin{array}{l}\text { Positivo no cultivo geral em } \\
\begin{array}{l}\text { aspirados de linfonodos } \\
{ }^{c}\end{array}\end{array}$ & 23 & 0 & 23 \\
$\begin{array}{l}\text { Negativo no cultivo geral } \\
\text { em aspirados de linfonodos }\end{array}$ & 14 & 55 & 69 \\
\hline Total & 37 & 55 & 92 \\
\hline
\end{tabular}

${ }^{a}$ Cães infectados: cães com detecção de B. canis em amostras de sangue nos testes de hemocultura e/ou PCR.

${ }^{\text {b }}$ Caes não infectados: cães com resultados negativos na hemocultura e na PCR aplicada em amostras de sangue para detecção de B. canis.

${ }^{\mathrm{c}}$ Foram considerados como positivos no cultivo microbiológico geral em amostras de aspirados de linfonodos, os cães nos quais houve isolamento de $B$. canis pelo protocolo de cultivo direto e/ou pelo enriquecimento em caldo. 


\begin{abstract}
${ }^{\mathrm{d}}$ Foram considerados como negativos no cultivo microbiológico geral em amostras de aspirados de linfonodos, os cães com resultado negativo no cultivo microbiológico pelo protocolo de cultivo direto e pelo enriquecimento em caldo.
\end{abstract}

Sensibilidade diagnóstica do cultivo geral de aspirados de linfonodos: $62 \%$

Especificidade diagnóstica do cultivo geral de aspirados de linfonodos: 100\%

Tabela 7. Sensibilidade e especificidade diagnóstica do diagnóstico direto aplicado à detecção de Brucella canis em amostras de aspirados de linfonodos caninos (situação 5).

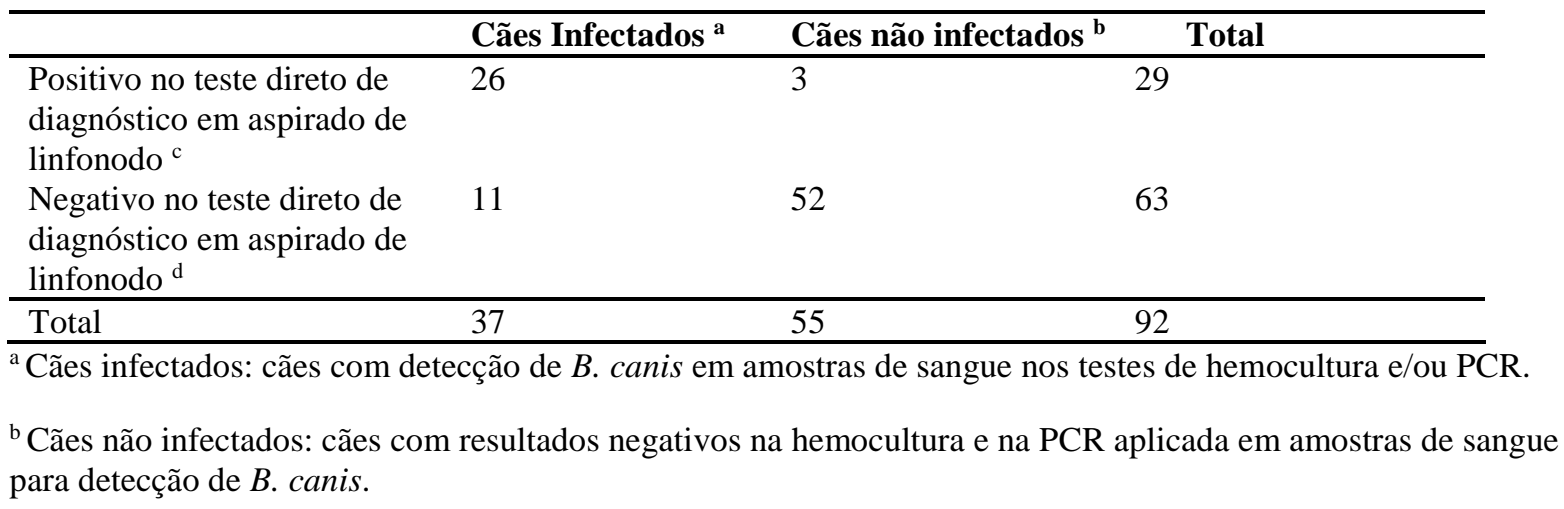

${ }^{c}$ Foram considerados como positivos no teste direto de diagnóstico os cães que apresentaram resultado positivo em amostras de aspirados de linfonodos em pelo menos um dos métodos direto de diagnóstico usados: cultivo microbiológico direto, cultivo microbiológico pelo enriquecimento em caldo ou PCR.

\footnotetext{
${ }^{\mathrm{d}}$ Foram considerados como negativos no teste direto de diagnóstico os cães com resultado negativo nos três métodos diretos de diagnóstico usados: cultivo microbiológico direto, cultivo microbiológico com enriquecimento em caldo e PCR.
}

Sensibilidade diagnóstica do teste direto aplicado às amostras de aspirados de linfonodos: $70 \%$

Especificidade diagnóstica do teste direto aplicado às amostras de aspirados de linfonodos: 95\%

Dos 29 cães que apresentaram resultado positivo em pelo menos um dos testes diretos utilizados para detecção de B. canis em amostras de aspirados de linfonodos, 25 apresentaram pelo menos um sinal clínico sugestivo de brucelose e destes, 18 tiveram manifestações reprodutivas. Dentre os 18 cães nos quais foram evidenciados transtornos reprodutivos, a ocorrência de abortamentos/nascimento de filhotes mortos e a presença de secreção vaginal fora do período do estro foram as manifestações mais comumente observadas (11 fêmeas abortaram e 11 fêmeas apresentaram secreção vaginal), seguido de falhas de concepção (observadas em três fêmeas).

Sete cães apresentaram aumento do volume de linfonodos e resultados positivos nos testes laboratoriais diretos utilizados para detecção de Brucella em aspirados de linfonodos, enquanto que nove cães foram positivos no teste direto apesar de não terem sido verificados 
linfonodos aumentados durante o exame clínico. Dentre os 63 cães com resultados negativos nos testes diretos, 17 apresentaram pelo menos um linfonodo aumentado ao exame clínico.

Três cães pertencentes ao grupo de cães não infectados apresentaram resultados positivos na PCR em aspirado de linfonodo. Estes indivíduos pertenciam a canis nos quais o teste padrão ouro diagnosticou pelo menos um animal infectado por B. canis. Além disso, há relato de abortamento em um destes animais.

A tabela 8 compreende os valores de sensibilidade e especificidade diagnóstica do EIC em relação ao padrão ouro.

Tabela 8. Sensibilidade e especificidade diagnóstica do ensaio imunocromatográfico (EIC) utilizado para o diagnóstico sorológico da infecção por Brucella canis em 92 cães.

\begin{tabular}{|c|c|c|c|}
\hline & Cães Infectados ${ }^{\text {a }}$ & Cães não infectados ${ }^{b}$ & Total \\
\hline Positivo no EIC & 34 & 6 & 40 \\
\hline Negativo no EIC & 3 & 49 & 52 \\
\hline Total & 37 & 55 & 92 \\
\hline
\end{tabular}

Sensibilidade diagnóstica do EIC: $92 \%$

Especificidade diagnóstica do EIC: $89 \%$

Dos 40 animais com resultados positivos no EIC, 37 apresentaram pelo menos uma manifestação clínica sugestiva de brucelose, sendo que afecções reprodutivas foram verificadas em 21 destes cães. A manifestação reprodutiva mais comumente observada foi o abortamento/falha de concepção (verificado em 16 fêmeas), seguido pela presença de secreção vaginal fora do período do estro (em 12 fêmeas) e por falhas na concepção (relatado em seis fêmeas). Dos 52 cães com sorologia negativa, 12 apresentaram sinais clínicos compatíveis com brucelose, sendo que em sete destes, manifestações reprodutivas foram relatadas.

O EIC classificou seis cães como positivos dentre os cães considerados não infectados de acordo com o padrão ouro utilizado. Todos estes cães são pertencentes a canis nos quais o padrão ouro detectou pelo menos um animal infectado por B. canis (canil foco de brucelose). Além disso, cinco destes animais apresentaram sinais clínicos sugestivos de brucelose. $\mathrm{O}$ animal que não apresentou sinal clínico também apresentou resultado positivo na PCR de aspirado de linfonodo. 
Dos três animais infectados, mas com resultados negativos nas amostras de soro pelo EIC, um foi proveniente de um canil foco de brucelose e apresentou sinal clínico compatível com brucelose (falha na concepção e aumento de linfonodos), além de resultados positivos na hemocultura e na PCR aplicada a amostras de sangue. Os demais também apresentaram resultado positivo na PCR em amostras de sangue. Estes cães são pertencentes a um canil no qual transtornos reprodutivos foram relatados em alguns animais. Neste canil não houve isolamento de $B$. canis de nenhum animal, mas a infecção foi evidenciada pelos resultados obtidos na PCR em sangue em dois cães deste plantel. Um destes cães também foi positivo na PCR aplicada em amostras de aspirados de linfonodos.

Os valores de sensibilidade e especificidade diagnóstica considerando-se conjuntamente os resultados obtidos no EIC e no teste direto para detecção de $B$. canis em amostras de aspirados de linfonodos podem ser verificados na Tabela 9. Neste caso, foram considerados como positivos os cães reagentes em pelo menos um dos testes laboratoriais utilizados para o diagnóstico da infecção por B. canis (EIC, cultivo microbiológico ou PCR aplicados em amostras de aspirados de linfonodos).

Tabela 9. Sensibilidade e especificidade diagnóstica considerando-se conjuntamente os resultados obtidos no EIC e no teste direto para detecção de Brucella canis em amostras de aspirados de linfonodos.

\begin{tabular}{|c|c|c|c|}
\hline & Cães Infectados ${ }^{a}$ & Cães não infectados ${ }^{b}$ & Total \\
\hline $\begin{array}{l}\text { Positivo no teste direto e/ou } \\
\text { no teste sorológico }\end{array}$ & 36 & 8 & 44 \\
\hline $\begin{array}{l}\text { Negativo no teste direto e no } \\
\text { teste sorológico }{ }^{\mathrm{d}}\end{array}$ & 1 & 47 & 48 \\
\hline Total & 37 & 55 & 92 \\
\hline
\end{tabular}

${ }^{\mathrm{c}}$ Foram considerados como positivos os cães que apresentaram resultado positivo em pelo menos um dos testes laboratoriais utilizados: cultivo microbiológico direto de aspirados de linfonodos, cultivo microbiológico com enriquecimento em caldo em aspirados de linfonodos, PCR de aspirados de linfonodos, ou EIC em amostras de soro.

${ }^{\mathrm{d}}$ Foram considerados como negativos teste direto de diagnóstico os cães com resultado negativo em todos os testes laboratoriais utilizados: cultivo microbiológico direto de aspirados de linfonodos, cultivo microbiológico com enriquecimento em caldo em aspirados de linfonodos, PCR de aspirados de linfonodos e EIC em amostras de soro.

Sensibilidade diagnóstica do teste direto e/ou teste sorológico: 97\%

Especificidade diagnóstica do teste direto e teste sorológico: $86 \%$

$\mathrm{O}$ animal infectado que apresentou resultado negativo no EIC e nos testes laboratoriais diretos utilizados para a detecção de Brucella é pertencente a um canil no qual transtornos 
reprodutivos foram relatados em alguns animais, mas não houve isolamento de $B$. canis de nenhum animal do plantel. A infecção foi evidenciada neste cão pelo resultado positivo na PCR em sangue e este cão não apresentou sinais clínicos sugestivos da infecção.

Dos oito cães não infectados, diagnosticados como positivos pelo EIC ou pelos testes diretos aplicados às amostras de aspirados de linfonodos, todos são pertencentes a canis considerados focos de brucelose, nos quais a infecção foi evidenciada em pelo menos um animal destas criações, por meio de cultivo microbiológico ou da PCR em amostras de sangue. Destes, seis apresentaram sinais clínicos compatíveis com brucelose.

As estimativas pontuais e intervalares da sensibilidade e especificidade estão apresentadas no gráfico 1 .

Gráfico 1. Estimativas pontuais e intervalares da sensibilidade e especificidade diagnóstica dos testes realizados neste trabalho.






\section{DISCUSSÃO}

O isolamento de B. canis em amostras de sangue canino vem sendo realizado com sucesso empregando-se protocolos baseados no enriquecimento prévio das amostras em meio líquido não seletivo, com incubação prolongada e subcultivos frequentes em ágar (KEID et al., 2007c). A maior eficiência deste tipo de protocolo quando comparado aos protocolos baseados no cultivo direto em ágar para o isolamento de Brucella em amostras de sangue deve-se à natureza intracelular do patógeno, que se encontra no interior de monócitos circulantes durante a fase de bacteremia, e ao crescimento lento destas bactérias em meios de cultura axênicos (ALTON et al., 1976), de maneira que o sucesso no isolamento bacteriano a partir destas amostras depende de protocolos de incubação prolongada até que ocorra lise de leucócitos infectados e consequente liberação bacteriana no meio extracelular (GAVIRIA-RUIZ; CARDONA-CASTRO, 1995). Além disso, a utilização de meios de cultura líquidos possibilita a inoculação de maiores volumes de amostra de sangue para o cultivo, aumentando-se assim as chances de isolamento.

Nos tecidos linfoides, como nos linfonodos, espera-se que a bactéria esteja presente no interior de macrófagos e à semelhança das amostras de sangue, infere-se que a incubação prolongada em meio líquido possa aumentar as taxas de isolamento. Assim, dois protocolos diferentes de cultivo foram avaliados no presente trabalho para as amostras linfoides, contudo, não foram verificadas diferenças de desempenho entre eles. A concordância entre os dois métodos de cultivo em amostras de linfonodos, calculada pelo coeficiente Kappa considerandose os 92 cães examinados, foi de $0,99 \%$, sendo considerada quase perfeita. Nenhum animal apresentou resultado positivo no cultivo em caldo e negativo no cultivo direto, enquanto que quatro cães foram positivos no cultivo direto e negativos no cultivo em caldo.

Das quatro amostras de aspirados de linfonodos que foram positivas no cultivo direto e negativas no cultivo em caldo, duas apresentaram contaminação bacteriana secundária, o que pode ser esperado, uma vez que foi utilizado meio de cultivo líquido não seletivo, que pode favorecer o crescimento de contaminantes secundários. Cabe ressaltar que, conceitualmente, estes resultados poderiam ser definidos como inconclusivos, uma vez que a presença de contaminantes pode sobrepor ao crescimento de Brucella, não necessariamente indicando a ausência desta nas amostras. Contudo, a maior propensão à contaminação bacteriana pode ser considerada uma característica inerente ao protocolo de isolamento baseado no enriquecimento 
prévio em caldo, que prejudicou o isolamento do Brucella. Assim, para efeito das análises de comparação do desempenho entre os testes, realizadas neste trabalho, as amostras que apresentaram contaminação secundária foram classificadas como negativas, e não como inconclusivas.

A principal desvantagem dos métodos de cultivo baseados no enriquecimento prévio das amostras é a maior possibilidade de contaminação bacteriana secundária, devido ao crescimento lento das brucelas em meios de cultura e do uso de meios não seletivos. Nos protocolos de cultivo direto em meio sólido (ágar), geralmente é possível a individualização das colônias de Brucella isoladas, mesmo na presença de contaminantes. Assim, o enriquecimento prévio tende a ser mais eficiente para o isolamento de amostras biológicas que possam ser obtidas de maneira asséptica e sem a presença de componentes da microbiota do hospedeiro (ALTON et al., 1976).

A utilização de caldos seletivos para o enriquecimento prévio das amostras visando ao isolamento de Brucella seria uma opção para reduzir as chances de contaminação secundária. Há diversos meios seletivos disponíveis contendo diferentes composições de antimicrobianos (BROWN et al., 1971; MARÍN et al., 1996; HER et al., 2010; DE MIGUEL et al., 2011; VICENTE et al., 2014; OIE, 2015), contudo, os meios altamente seletivos como o meio de Farrell (FARRELL, 1974), são sabidamente inibitórios para algumas espécies e estirpes de Brucella, incluindo as espécies rugosas como B. canis e B. ovis (MARÍN et al., 1996). Outras formulações de meios, consideradas menos seletivas, estão disponíveis e poderiam ser usadas para o isolamento de B. canis (THAYER; MARTIN, 1966; BROWN et al., 1971), porém, estas são menos eficientes em inibir contaminações secundárias, o que poderia comprometer o isolamento de B. canis, especialmente quando da utilização de meios líquidos.

Ademais, há pouca informação disponível sobre a suscetibilidade antimicrobiana de estirpes brasileiras de B. canis (MAGALHÃES NETO et al., 2014), bem como de estudos visando à avaliação do desempenho de meios seletivos para o isolamento de B. canis (DE MIGUEL et al., 2011). Optou-se, portanto, por utilizar meios não seletivos com o intuito de garantir o isolamento de estirpes potencialmente suscetíveis às formulações antimicrobianas empregadas nos meios seletivos atualmente disponíveis para o isolamento de Brucella. $\mathrm{O}$ procedimento de coleta das amostras de aspirados de linfonodos foi precedido de tricotomia seguida de assepsia com álcool 70\% e limpeza do local da punção utilizando-se gazes estéreis, o que possibilitou a realização do cultivo com mínimas taxas de contaminação secundária 
(apenas duas das 92 amostras semeadas no meio de enriquecimento apresentaram o crescimento de contaminantes de maneira a prejudicar o isolamento de Brucella).

Um maior sucesso no isolamento de Brucella foi verificado na hemocultura em comparação ao cultivo de amostras de linfonodos, sendo que a concordância entre a hemocultura e o método direto de cultivo de aspirados de linfonodos foi substancial (valor de Kappa de 0,85), enquanto que uma menor concordância (moderada) foi verificada entre a hemocultura e o cultivo em caldo de aspirados de linfonodos (valor de Kappa de 0,75), considerando-se os 92 cães amostrados.

Ao avaliar a sensibilidade diagnóstica dos dois métodos de cultivo de aspirados de linfonodos, considerando-se o grupo de cães infectados, verificou-se valores de sensibilidade de $62 \%$ para o método de cultivo direto e $51 \%$ para o método de cultivo em caldo.

Uma das possíveis explicações para o melhor desempenho do cultivo em caldo para isolamento de Brucella em sangue em relação às amostras de aspirados de linfonodos é o maior volume de amostra utilizado para o cultivo de sangue. Apesar de o cultivo em caldo possibilitar a inoculação de maiores volumes de amostra, o procedimento de colheita utilizado para a obtenção de amostras linfoides (punção aspirativa) não permitiu a obtenção de grandes volumes de amostra. A reduzida quantidade de conteúdo celular obtida foi ressuspendida em $500 \mu \mathrm{L}$ de solução salina estéril e volumes iguais $(100 \mu \mathrm{L})$ foram utilizados nos dois protocolos de cultivo.

A especificidade diagnóstica dos dois métodos de cultivo microbiológico utilizados foi de $100 \%$, considerando-se os 55 cães não infectados. A alta especificidade dos protocolos de cultivo microbiológico é um resultado esperado, uma vez que o isolamento bacteriano é acompanhado de métodos de identificação baseados em diversas características (morfológicos, tintoriais e moleculares), possibilitando uma identificação inequívoca dos isolados.

A concordância entre a PCR empregada em aspirados de linfonodos e os métodos de cultivo direto e em caldo (considerados separadamente e em conjunto), calculada pelo coeficiente Kappa considerando-se os 92 cães examinados, foi considerada substancial (Tabela 2). Seis cães foram negativos nos dois métodos de cultivo, porém positivos na PCR em aspirados de linfonodos, enquanto que dois cães foram positivos em pelo menos um dos métodos de cultivo, porém negativos na PCR. 
Ao comparar os valores de sensibilidade diagnóstica do cultivo microbiológico geral e da PCR aplicados em amostras de aspirados de linfonodos, verificou-se que a sensibilidade diagnóstica do teste molecular $(65 \%)$ foi pouco superior à sensibilidade do cultivo microbiológico geral $(62 \%)$.

A superioridade do método de PCR em relação ao cultivo microbiológico para a detecção de Brucella em cães já foi evidenciada em outros estudos, que empregaram amostras de sangue (KEID et al., 2007c; BATINGA et al., 2017), swab vaginal (KEID et al., 2007a), sêmen (KEID et al., 2007b) e urina (SALGADO, 2006). A detecção de um maior número de positivos nos testes moleculares em relação ao diagnóstico microbiológico é um resultado esperado em razão da capacidade do teste molecular de detectar reduzidas quantidades de DNA de Brucella nas amostras, independentemente da viabilidade da bactéria e da presença de contaminantes secundários (BRICKER, 2002; YANG; ROTHMAN, 2004).

O protocolo de PCR empregado para a detecção direta de Brucella foi baseado no uso de primers direcionados à IS711 (BATINGA, 2017), elemento repetitivo presente em número variável de cópias dispersas no genoma, conforme a espécie de Brucella. Na estirpe de referência de B. canis (RM6/66) foram identificadas seis cópias de IS711, o que certamente contribui para aumentar a sensibilidade do teste de PCR (HALLING et al., 1993; OUAHRANI et al., 1993; OCAMPO-SOSA; GARCÍA-LOBO, 2008; BOUNAADJA et al., 2009; MANCILLA et al., 2011).

Apesar da elevada sensibilidade diagnóstica do teste molecular em relação ao cultivo microbiológico, duas amostras apresentaram resultado positivo no cultivo microbiológico (uma amostra foi positiva apenas no método direto e uma foi positiva nos dois métodos de cultivo) mas resultado negativo na PCR. Resultados desta natureza podem ser indicativos da presença de inibidores nas amostras capazes de interferir na reação da amplificação de ácidos nucléicos. Diversos componentes já foram identificados como potenciais inibidores da PCR, os quais podem compreender substâncias naturalmente presentes nas amostras ou compostos gerados nos procedimentos de extração e purificação de ácidos nucléicos (AKANE et al., 1994; COGSWELL et al., 1996; AL-SOUD; RADSTROM, 2001; AMIN et al., 2001).

Contudo, no presente trabalho, a alta sensibilidade analítica observada $(134,6 \mathrm{fg} / \mu \mathrm{l})$ no teste molecular atesta a eficiência do protocolo de purificação em gerar DNA de elevada qualidade. Os valores similares de sensibilidade analítica observados na presença e na ausência 
de DNA canino indicam ausência de interferência do DNA do hospedeiro no processo de amplificação (BATINGA et al., 2017).

No procedimento de colheita de amostras de aspirados de linfonodos por punção aspirativa, pequenas quantidades de material celular foram obtidas, e em seguida ressuspendidas em solução salina. Por se tratar de material particulado, este pode não estar presente de maneira homogênea na suspensão formada, não estando disponível em quantidade suficiente para todos os procedimentos diagnósticos usados.

Já a especificidade do teste de PCR realizado em amostras de aspirados de linfonodos foi de $95 \%$. Dos 55 cães considerados não infectados, três foram positivos na PCR em aspirado de linfonodo. Reações inespecíficas em testes moleculares baseados na amplificação enzimática de ácidos nucléicos podem ocorrer quando da utilização de primers capazes de hibridizar totalmente ou parcialmente em sequências de outros organismos presentes nas amostras, especialmente no caso de organismos geneticamente relacionados ao organismo alvo. As sequências de inserção IS711, porém, são elementos genéticos exclusivos do gênero Brucella, sendo considerados marcadores gênero-específicos (HALLING et al., 1993; BOUNAADJA et al., 2009)

O primers utilizados no presente trabalho foram previamente avaliados quanto à sua especificidade analítica, utilizando-se um painel de isolados bacterianos, representando bactérias comumente diagnosticadas em cães, bem como bactérias geneticamente relacionadas ao gênero Brucella, como as espécies Ochrobactrum anthropi e Ochrobactrum intermedium, tendo sido comprovada a elevada especificidade analítica dos primers (BATINGA, 2017). Neste mesmo estudo, a especificidade diagnóstica dos primers foi considerada elevada quando de sua utilização para o diagnóstico da brucelose canina utilizando um painel de amostras de sangue provenientes de cães não infectados.

Dois, dos três cães pertencentes ao grupo de animais não infectados que apresentaram resultados positivos na PCR em aspirados de linfonodos eram provenientes de um canil considerado foco de brucelose [houve isolamento de B. canis em amostras de sangue de 54,5\% (18/33) da população canina presente neste canil]. Um destes cães apresentou resultado negativo nas amostras de soro pelo EIC, mas apresentou aumento do volume de linfonodos e falha de concepção, enquanto que o segundo animal foi positivo no EIC, apesar de assintomático. Devido às características de manejo observadas nesta criação, na qual os animais 
eram mantidos em baias coletivas e em ambiente com pouca ventilação, os resultados sugerem que os resultados falsos positivos identificados sejam, na verdade indicativos de infecção por B. canis.

O terceiro cão que apresentou resultado positivo na PCR em aspirado de linfonodo apresentou resultado negativo pelo EIC e sinais clínicos da infecção não foram verificados, porém, foi proveniente de um canil no qual transtornos reprodutivos foram relatados em outros animais (os quais não estavam presentes no momento da coleta, portanto, não foram amostrados), mas não houve isolamento de B. canis de nenhum dos 19 animais testados. Destes 19 cães, dois foram positivos na PCR em sangue, indicando que o canil seja foco de infecção e sugerindo que o animal com resultado positivo na PCR em aspirado de linfonodos possa também ser considerado um animal infectado.

Cães não bacterêmicos, porém positivos na PCR em amostras de aspirados de linfonodos podem apresentar-se numa fase mais adiantada da infecção, com declínio da bacteremia, mas persistência bacteriana em tecidos linfoides, no interior de macrófagos (BYNDLOSS; TSOLIS, 2016). Outra possível explicação seria a ocorrência da bacteremia intermitente nestes cães, fenômeno já descrito na infecção por B. canis em cães (GREENE; CARMICHAEL, 2006).

A associação do cultivo microbiológico ao teste molecular para a detecção de Brucella nas amostras de aspirados de linfonodos possibilitou um aumento da sensibilidade diagnóstica de $62 \%$ para $70 \%$, em relação ao grupo de cães infectados. Já a concordância entre os testes diretos de diagnóstico (cultivo e PCR analisados conjuntamente) aplicados às amostras de aspirados de linfonodos e às amostras de sangue, considerando-se os 92 cães examinados, foi considerada substancial, com um valor de Kappa de 0,82. Das 29 amostras de aspirados de linfonodos positivas nos testes laboratoriais diretos utilizados para a detecção de Brucella, 26 foram provenientes de cães em bacteremia.

Cabe ressaltar que em um dos canis avaliados, a confirmação da infecção foi possível apenas com a utilização do teste molecular. A informação foi confirmada em quatro dos 19 avaliados, sendo um positivo tanto na PCR em sangue quanto na PCR em linfonodo, um positivo apenas na PCR em sangue e um positivo apenas na PCR em aspirado de linfonodo. Ressalta-se, que episódios de abortamento foram relatados neste canil, porém, nem todos os 
cães do plantel foram amostrados. Nenhum dos 19 cães amostrados apresentou transtornos reprodutivos associados à brucelose ou apresentou resultados positivos no teste sorológico.

Apenas três animais foram positivos nas amostras de aspirados de linfonodos e negativos nas amostras de sangue, o que pode ser consequência da distribuição não homogênea da bactéria nos tecidos linfoides após cessada a bacteremia, dificultando a detecção de animais infectados (além das características inerentes aos protocolos de cultivo utilizados, as quais já foram discutidas anteriormente). De cada animal, foi colhida amostra de apenas um dos linfonodos poplíteos, reduzindo as chances de detecção no caso de distribuição não homogênea da bactéria.

O valor de sensibilidade diagnóstica do EIC (92\%) aplicado ao sorodiagnóstico da infecção por B. canis foi superior aos valores obtidos quando da utilização dos testes de cultivo e PCR conjuntamente para o diagnóstico direto da infecção em amostras de aspirados de linfonodos (70\%). As diferenças observadas são explicáveis pelos diferentes princípios dos métodos de diagnóstico (detecção direta bacteriana e detecção de anticorpos séricos). Já a concordância entre o EIC e os testes de diagnóstico direto da infecção em amostras de aspirados de linfonodos foi considerada moderada (valor de Kappa de 0,73). Quinze cães foram positivos apenas no EIC e quatro cãs foram positivos apenas nos testes diretos em linfonodos.

Já a concordância entre o EIC e os testes de diagnóstico direto da infecção em amostras de sangue foi considerado substancial (valor de Kappa de 0,92). Dos 92 cães analisados, apenas seis foram positivos apenas no EIC e três foram positivos apenas nos testes diretos utilizados para a detecção de Brucella em sangue.

A elevada concordância observada entre o teste sorológico e o diagnóstico laboratorial direto em sangue pode sugerir que este teste sorológico priorize a detecção de cães durante a fase de bacteremia. Estudos prévios já indicaram uma maior sensibilidade dos testes sorológicos baseados em antígenos de parede celular para o diagnóstico da brucelose canina em cães durante o período de bacteremia (ZOHA; CARMICHAEL, 1982; KEID et al., 2009; WANKE et al., 2012; KEID et al., 2015). Este resultado é compreensível, uma vez que em infecções por bactérias intracelulares facultativas, como as pertencentes ao gênero Brucella, a natureza intracelular do patógeno oferece reduzido estímulo antigênico para desenvolvimento da resposta imune humoral, a qual é induzida geralmente durante manifestação da bacteremia, 
quando há maior disseminação do patógeno no organismo do hospedeiro (DORNELES et al., 2015).

Keid et al. (2009), ao avaliar o desempenho de testes sorológicos para o diagnóstico da brucelose em cães infectados na presença e na ausência de bacteremia, verificaram menores valores de sensibilidade destes testes na ausência de bacteremia. Neste estudo, a proporção de cães infectados não bacterêmicos que apresentaram resultados sorológicos negativos foi de 59\% (13/22) para o teste de SAR, 100\% (22/22) para o teste de SAR-2ME e 54,5\% (12/22) para o teste de IDGA. Estes cães foram diagnosticados como infectados por apresentarem resultados positivos no cultivo e/ou PCR empregados em amostras genitais (sêmen e $s w a b$ vaginal).

Dos 37 cães pertencentes ao grupo de cães infectados, três foram negativos no EIC, o que pode ser um indicativo de que estes animais se apresentavam na fase inicial da infecção, com presença de bacteremia, mas ausência de soroconversão. Nas infecções caninas por $B$. canis, a bacteremia tem início entre 1 e 4 semanas pós-infecção (CARMICHAEL; KENNEY, 1970; LARSSON et al., 1984; KIM et al., 2007), porém, os títulos de anticorpos tornam-se detectáveis nos testes sorológicos, em média, após 3 a 12 semanas pós-infecção, dependendo do tipo de antígeno e da plataforma diagnóstica utilizada (ZOHA; CARMICHAEL, 1982; LARSSON et al., 1984; KIM et al., 2007).

Já a especificidade diagnóstica do EIC foi de 89\%, valor inferior ao relatado para este mesmo teste no estudo conduzido por KEID et al. (2015) e também ao valor observado no estudo de WANKE et al., (2012) ao avaliar um teste similar. Em ambos os estudos, o valor de especificidade diagnóstica foi de $100 \%$.

A ocorrência de cães com resultados positivos no sorodiagnóstico, mas negativos nos métodos diretos de diagnóstico poderia ser explicada pela ocorrência de resultados falsopositivos nos testes sorológicos, decorrentes de reações entre os antígenos utilizados e anticorpos não específicos presentes no soro de cães não infectados por B. canis. Já foram relatadas, na literatura científica, reações inespecíficas devido ao compartilhamento de antígenos de parece celular entre B. ovis e Streptococcus faecalis, Staphylococcus epidermidis e Pseudomonas aeruginosa, levando a resultados falso-positivos no teste de IDGA (CARMICHAEL; JOUBERT, 1987), bem como com Bordetella bronshiseptica, acarretando resultados falsos positivos no teste de aglutinação (GEORGE; CARMICHAEL, 1974). Reações inespecíficas, porém, parecem ser mais comumente relatadas nos testes de aglutinação 
(FLORES-CASTRO; CARMICHAEL 1978; CARMICHAEL. 1990; KEID et al., 2009; KEID et al., 2015).

No presente estudo, os seis cães que foram negativos na hemocultura e na PCR em amostras de sangue, mas que apresentaram resultados positivos no EIC pertenciam a dois canis considerados focos de brucelose, nos quais a prevalência da infecção (evidenciada pelos testes de hemocultura e PCR em sangue) foi, respectivamente, de $82 \%$ e $61 \%$. Além disso, cinco destes cães apresentaram sinais clínicos compatíveis com brucelose durante o exame clínico (três cães apresentaram apenas linfonodos aumentados, uma fêmea apresentou apenas abortamento e uma fêmea, abortamento e linfonodomegalia). Estas informações podem sugerir que os resultados sorológicos positivos detectados no grupo de cães não infectados na presente proposta, sejam na verdade decorrentes de infecção por B. canis.

As diferenças nos valores de especificidade diagnóstica relatados ao comparar o presente estudo com estudos prévios, também baseados em ensaios imunocromatográficos para o diagnóstico da brucelose canina, podem ser consequência dos diferentes critérios utilizados para a definição dos grupos padrão ouro. No estudo de Keid et al. (2015), foram utilizados cães que atendiam a todos seguintes critérios para compor o grupo de animais não infectados, utilizado para aferir a especificidade do EIC: negativos em testes microbiológicos e moleculares aplicados a amostras de sangue e genitais, sem sinais clínicos sugestivos de brucelose e provenientes de canis que não apresentaram evidências clínicas, sorológicas e microbiológicas de brucelose em nenhum cão. No presente estudo, um critério menos restritivo foi utilizado para selecionar cães não infectados para aferição da especificidade diagnóstica dos testes, uma vez que foram selecionados cães negativos no teste microbiológico e molecular em amostras de sangue, independentemente da condição epidemiológica dos mesmos. Este critério foi utilizado pois informações confiáveis quanto à situação epidemiológica (especialmente quanto à possibilidade de contato com cães infectados) de todos os cães utilizados neste estudo não estavam disponíveis.

A associação do EIC aos testes diretos para detecção de Brucella em amostras de aspirados de linfonodos, possibilitou um aumento da sensibilidade diagnóstica para 97\%, com a identificação de 34 dos 37 cães pertencentes ao grupo infectado. A especificidade do teste, porém, foi reduzida para $89 \%$, considerando-se o grupo de cães não infectados. Tendo em vista que os oito cães provenientes do grupo não infectado que apresentaram resultados positivos no teste sorológico e/ou teste direto em aspirados de linfonodos (sendo um positivo em ambos os 
testes, três positivos apenas no teste direto em linfonodo e cinco positivos apenas no teste sorológico) eram provenientes dos três canis amostrados considerados focos de brucelose, esta redução da especificidade diagnóstica pode, na verdade, ser consequência de uma maior capacidade destes testes em detectar cães não bacterêmicos. As condições de manejo destas criações reuniam algumas práticas que podem favorecer a rápida disseminação da infecção entre os cães, tais como a manutenção dos cães em baias comuns e em alta densidade, a inexistência de baias maternidade para segregação das fêmeas gestantes e medidas de desinfecção deficientes. Assim, as chances de que estes animais tenham sido infectados e apresentem-se não bacterêmicos é elevada. 


\section{CONCLUSÕES}

Diante dos resultados apresentados, pode-se concluir que:

1) Houve pouca diferença entre os dois métodos de cultivo microbiológico aplicados às amostras de aspirados de linfonodos quanto à sensibilidade diagnóstica, porém, o cultivo direto em ágar mostrou-se menos laborioso em relação ao cultivo em caldo, sendo mais aplicável ao isolamento de B. canis nestas amostras.

2) A PCR em amostras de aspirados de linfonodos apresentou maior sensibilidade em relação aos métodos de cultivo aplicados a estas amostras, sendo uma alternativa ao diagnóstico microbiológico.

3) O EIC aplicado às amostras de soro apresentou elevada sensibilidade, sendo uma alternativa rápida, prática e segura para detecção da doença em canis onde haja a suspeita da infecção por B. canis.

4) A associação entre os testes de PCR em amostras de aspirados de linfonodos e de sangue e o EIC possibilitou a detecção de um maior número de cães positivos, por possibilitar a identificação de cães infectados por $B$. canis na ausência e na presença de bacteremia, além de possibilitar maior rapidez no diagnóstico em relação ao cultivo. 


\section{REFERÊNCIAS}

ACHA, P.; SZYFRES, B. Zoonosis y enfermidades transmisibles comunes al hombre y a los animales. 3. ed. Washngton: O.P.S., 2001.

AGUIAR, D. M. DE; CAVALCANTE, G. T.; VASCONCELLOS, S. A.; MEGID, J.; SALGADO, V. R.; CRUZ, T. F.; LABRUNA, M. B.; PINTER, A.; SILVA, J. C. R. DA; MORAES, Z. M.; CAMARGO, L. M. A.; GENNARI, S. M. Ocorrência de anticorpos antiBrucella abortus e anti-Brucella canis em cães rurais e urbanos do Município de Monte Negro, Rondônia, Brasil. Ciência Rural, v. 35, n. 5, p. 1216-1219, 2005.

AKANE, A.; MATSUBARA, K.; NAKAMURA, H.; TAKAHASHI, S.; KIMURA, K. Identification of the heme compound copurified with deoxyribonucleic acid (DNA) from bloodstains, a major inhibitor of polymerase chain reaction (PCR) amplification. Journal of Forensic Sciences, v. 39, n. 2, p. 362-72, 1994.

AL-SOUD, W. A.; RADSTROM, P. Purification and Characterization of PCR-Inhibitory Components in Blood Cells. Journal of Clinical Microbiology, v. 39, n. 2, p. 485-493, 2001.

ALMEIDA, A. C.; SANTORELli, A.; BRUZADELLI, R. M. Z.; OLIVEIRA, M. M. N. F. Soroepidemiologia da brucelose canina causada por Brucella canis e Brucella abortus na cidade de Alfenas, MG. Arquivo Brasileiro de Medicina Veterinária e Zootecnia, v. 56, n. 2, p. 275-276, 2004.

ALTON, G. G.; JONES, L. M.; ANGUS, R. D.; VERGER, J. M. Techniques for the brucellosis laboratory. Paris: INRA, 1976.

AMIN, A. S.; HAMDY, M. E.; IBRAHIM, A. K. Detection of Brucella melitensis in semen using the polymerase chain reaction assay. Veterinary Microbiology, v. 83, n. 1, p. 37-44, 2001.

ANGEL, M. O.; RISTOW, P.; KO, A. I.; DI-LORENZO, C. Serological trail of Brucella infection in an urban slum population in Brazil. Journal of Infection in Developing countries, v. 6, n. 9, p. 675-679, 2012.

ARAS, Z.; UÇAN, U. S. Detection of Brucella canis from inguinal lymph nodes of naturally infected dogs by PCR. Theriogenology, v. 74, n. 4, p. 658-62, 2010.

ARESE, A.; CRAVERO, S.; BOSCHIROLI, M.; CAMPOS, E.; SAMARTINO, L.; ROSSETTI, O. [Use of a recombinant protein from Brucella abortus for the diagnosis of brucellosis in different animal species]. Revista Argentina de Microbiología, v. 31 Suppl 1, p. 36-9, 1999.

AZEVEDO, S. S.; VASCONCELlOS, S. A.; ALVES, C. J.; KEID, L. B.; GRASSO, L. M. P. S.; MASCOLLI, R.; PINHEIRO, S. R. Inquérito sorológico e fatores de risco para a 
brucelose por Brucella canis em cães do município de Santana de Parnaíba, Estado de São Paulo. Pesquisa Veterinária Brasileira, v. 23, n. 4, p. 156-160, 2003.

BADAKHSH, F. F.; CARMICHAEL, L. E.; DOUGLASS, J. A. Improved rapid slide agglutination test for presumptive diagnosis of canine brucellosis. Journal of Clinical Microbiology, v. 15, n. 2, p. 286-289, 1982.

BALDI, P. C.; WANKE, M. M.; LOZA, M. E.; FOSSATI, C. A. Brucella abortus cytoplasmic proteins used as antigens in an ELISA potentially useful for the diagnosis of canine brucellosis. Veterinary Microbiology, v. 41, n. 1-2, p. 127-34, 1994.

BALDI, P.; WANKE, M.; LOZA, M. Diagnosis of canine brucellosis by detection of serum antibodies against an $18 \mathrm{kDa}$ cytoplasmic protein of Brucella spp. Veterinary Microbiology, v. 1135, n. 97, 1997.

BARROUIN-MELO, S. M.; POESTER, F. P.; RIBEIRO, M. B.; DE ALCÂNTARA, A. C.; AGUIAR, P. H. P.; NASCIMENTO, I. L.; SCHAER, R. E.; NASCIMENTO, R. M.; FREIRE, S. M. Diagnosis of canine brucellosis by ELISA using an antigen obtained from wild Brucella canis. Research in Veterinary Science, v. 83, n. 3, p. 340-6, 2007.

BATINGA, M. C. A. Diagnóstico molecular comparativo da brucelose canina pela aplicação das técnicas de reação em cadeia pela polimerase (PCR) e amplificação isotérmica do DNA mediada por loop (LAMP). [Comparative molecular diagnosis of canine brucellosis by application of polymerase chain reaction (PCR) techniques and loopmediated isothermal amplification (LAMP)]. 2017. 75 f. Dissertação (Mestrado em Ciências) - Faculdade de Medicina Veterinária e Zootecnia, 2017.

BEZERRA, R.; MENDONÇA, C.; MARA, P. Prevalência de anticorpos contra Brucella canis em cães na região de Ilhéus-Itabuna, estado da Bahia, Brasil. Revista Brasileira de Medicina Veterinária, v. 34, n. 1, p. 27-30, 2012.

BLANKENSHIP, R. M.; SANFORD, J. P. Brucella canis. A cause of undulant fever. The American journal of medicine, v. 59, n. 3, p. 424-426, 1975.

BOUNAADJA, L.; ALBERT, D.; CHÉNAIS, B.; HÉNAULT, S.; ZYGMUNT, M. S.; POLIAK, S.; GARIN-BASTUJI, B. Real-time PCR for identification of Brucella spp.: a comparative study of IS711, bcsp31 and per target genes. Veterinary microbiology, v. 137, n. 1-2, p. 156-64, 2009.

BRENNAN, S. J.; NGELEKA, M.; PHILIBERT, H. M.; FORBES, L. B.; ALLEN, A. L. Canine brucellosis in a Saskatchewan kennel. Canadian Veterinary Journal, v. 49, n. 7, p. 703-708, 2008.

BRICKER, B. J. PCR as a diagnostic tool for brucellosis. Veterinary microbiology, v. 90, n. 1-4, p. 435-446, 2002.

BROWN, G. M.; RANGER, C. R.; KELLEY, D. J. Selective media for the isolation of Brucella ovis. The Cornell veterinarian, v. 61, n. 2, p. 265-80, 1971. 
BYNDLOSS, M. X.; TSOLIS, R. M. Brucella spp. Virulence Factors and Immunity. Annual Review of Animal Biosciences, v. 4, n. 1, p. 111-127, 2016.

CARMICHAEL, L. E. Canine brucellosis: An annotated review with selected cautionary comments. Theriogenology, v. 6, n. 2-3, p. 105-116, 1976.

CARMICHAEL, L. E. Brucella canis. In: NIELSEN, K.; DUNCAN, J. R. (Eds.). . Animal Brucellosis. Boca Raton, Flórida: CRC Press, 1990. p. 335-350.

CARMICHAEL, L. E.; GREENE, C. E. Canine brucellosis. In: GREENE, C. E. (Ed.). . Infectious diseases of the dog and cat. Philadelphia: W. B. SAUNDERS, 1990. p. 573-584.

CARMICHAEL, L. E.; JOUBERT, J. C. A rapid slide agglutination test for the serodiagnosis of Brucella canis infection that employs a variant (M-) organism as antigen. The Cornell veterinarian, v. 77, n. 1, p. 3-12, 1987.

CARMICHAEL, L. E.; KENNEY, R. M. Canine brucellosis: the clinical disease, pathogenesis, and immune response. Journal of the American Veterinary Medical Association, v. 156, n. 12, p. 1726-1734, 1970.

CARMICHAEL, L. E.; SHIN, S. J. Canine brucellosis: a diagnostician's dilemma. Seminars in veterinary medicine and surgery (small animal), v. 11, n. 3, p. 161-165, 1996.

CARMICHAEL, L. E.; ZOHA, S. J.; FLORES-CASTRO, R. Problems in the serodiagnosis of canine brucellosis: dog responses to cell wall and internal antigens of Brucella canis.

Developments in biological standardization, v. 56, p. 371-83, 1984.

CASSATARO, J.; DELPINO, M. V; VELIKOVSKY, C. A.; BRUNO, L.; FOSSATI, C. A.; BALDI, P. C. Diagnostic usefulness of antibodies against ribosome recycling factor from Brucella melitensis in human or canine brucellosis. Clinical and Diagnostic Laboratory Immunology, v. 9, n. 2, p. 366-369, 2002.

CASSATARO, J.; PASQUEVICH, K.; BRUNO, L.; WALLACH, J. C.; FOSSATI, C. A.; BALDI, P. C. Antibody reactivity to Omp31 from Brucella melitensis in human and animal infections by smooth and rough Brucellae. Clin Diagn Lab Immunol, v. 11, n. 1, p. 111114, 2004.

CLAVAREAU, C.; WELLEMANS, V.; WALRAVENS, K.; TRYLAND, M.; VERGER, J. M.; GRAYON, M.; CLOECKAERT, A.; LETESSON, J. J.; GODFROID, J. Phenotypic and molecular characterization of a Brucella strain isolated from a minke whale (Balaenoptera acutorostrata). Microbiology (Reading, England), v. 144, p. 3267-3273, 1998.

CLOECKAERT, A.; BAUCHERON, S.; VIZCAINO, N.; ZYGMUNT, M. S. Use of recombinant BP26 protein in serological diagnosis of Brucella melitensis infection in sheep. Clinical and diagnostic laboratory immunology, v. 8, n. 4, p. 772-5, 2001.

COGSWELL, F. B.; BANTAR, C. E.; HUGHES, T. G.; GU, Y.; PHILIPP, M. T. Host DNA can interfere with detection of Borrelia burgdorferi in skin biopsy specimens by PCR. 
Journal of clinical microbiology, v. 34, n. 4, p. 980-2, 1996.

COHEN, J. A Coefficient of Agreement for Nominal Scales. Educational and Psychological Measurement, v. 20, n. 1, p. 37-46, 1960.

CORBEL, M. J. Brucellosis: an overview. Emerging infectious diseases, v. 3, n. 2, p. 213 221, 1997.

CORBEL, M.J.; BANAI, M. Genus Brucella Meyer and Shaw 1920, 173 AL. In: Garrity, G.M., editor. Bergey's manual of systematic bacteriology vol. 2: The Proteobacteria: Part B. Baltimore (MD): Williams and Wilkins, 2005. p. 377-388.

CORBEL, M. J.; STUART, F. A.; BREWER, R. A. Observations on serological crossreactions between smooth Brucella species and organisms of other genera. Developments in biological standardization, v. 56, p. 341-348, 1984.

DAMP, S.; CRUMRINE, M.; LEWIS, G. Microtiter plate agglutination test for Brucella canis antibodies. Applied microbiology, v. 25, n. 3, p. 489-490, 1973.

DE MIGUEL, M. J.; MARIN, C. M.; MUNOZ, P. M.; DIESTE, L.; GRILLO, M. J.; BLASCO, J. M. Development of a selective culture medium for primary isolation of the main Brucella species. Journal of Clinical Microbiology, v. 49, n. 4, p. 1458-1463, 2011.

DENTINGER, C. M.; JACOB, K.; LEE, L. V.; MENDEZ, H. A.; CHOTIKANATIS, K.; MCDONOUGH, P. L.; CHICO, D. M.; DE, B. K.; TILLER, R. V.; TRAXLER, R. M.; CAMPAGNOLO, E. R.; SCHMITT, D.; GUERRA, M. A.; SLAVINSKI, S. A. Human Brucella canis infection and subsequent laboratory exposures associated with a puppy, New York City, 2012. Zoonoses and Public Health, v. 62, n. 5, p. 407-414, 2015.

DORNELES, E. M. S.; SANTOS, H.; MINHARRO, S.; NASCIMENTO-ROCHA, J. M. DO; MATHIAS, L. A.; DASSO, M. G.; TIENSOLI, C. D.; HEINNEMAN, M. B.; LAGE, A. P. Anticorpos anti-Brucella canis e anti-Brucella abortus em cães de Araguaína, Tocantins.

Brazilian Journal of Veterinary Research and Animal Science, v. 48, n. 2, p. 167-171, 2011.

DORNELES, E. M. S.; TEIXEIRA-CARVALHO, A.; ARAÚJO, M. S. S.;

SRIRANGANATHAN, N.; LAGE, A. P. Immune response triggered by Brucella abortus following infection or vaccination. Vaccine, v. 33, n. 31, p. 3659-3666, 2015.

EISENBERG, T.; RISS, K.; SCHAUERTE, N.; GEIGER, C.; BLOM, J.; SCHOLZ, H. C. Isolation of a novel "atypical" Brucella strain from a bluespotted ribbontail ray (Taeniura lymma). Antonie van Leeuwenhoek, v. 110, n. 2, p. 221-234, 2017.

ERLICH, H. A.; GELFAND, D.; SNINSKY, J. J. Recent advances in the polymerase chain reaction. Science (New York, N.Y.), v. 252, n. 5013, p. 1643-51, 1991.

FARRELL, I. D. The development of a new selective medium for the isolation of Brucella abortus from contaminated sources. Research in veterinary science, v. 16, n. 3, p. 280-6, 
1974.

FORBES, L. B. Brucella abortus infection in 14 farm dogs. Journal of the American Veterinary Medical Association, v. 196, n. 6, p. 911-916, 1990.

FOSTER, G.; OSTERMAN, B. S.; GODFROID, J.; JACQUES, I.; CLOECKAERT, A. Brucella ceti sp. nov. and Brucella pinnipedialis sp. nov. for Brucella strains with cetaceans and seals as their preferred hosts. International journal of systematic and evolutionary microbiology, v. 57, n. 11, p. 2688-2693, 2007.

GAVIRIA-RUIZ, M. M.; CARDONA-CASTRO, N. M. Evaluation and comparison of different blood culture techniques for bacteriological isolation of Salmonella typhi and Brucella abortus. Journal of clinical microbiology, v. 33, n. 4, p. 868-71, 1995.

GEORGE, L. W.; CARMICHAEL, L. E. Development of a rose bengal stained plate-test antigen for the rapid diagnosis of Brucella canis infection. The Cornell veterinarian, v. 68, n. 4 , p. $530-43,1978$.

GODOY, A. M.; NEVES, J.; PERES, J. N.; BARG, L. Human laboratory infection with Brucella canis. Arquivo da Escola de Veterinária da Universidade Federal de Minas Gerais, v. 31, n. 1, p. 31-34, 1979.

GREENE, C. E.; CARMICHAEL, L. E. Canine brucellosis. In: GREENE, C. (Ed.). . Infectious diseases of the dog and cat. 3. ed. Philadelphia: WB Saunders, Co, 2006. p. 369381.

HALLING, S. M.; TATUM, F. M.; BRICKER, B. J. Sequence and characterization of an insertion sequence, IS711, from Brucella ovis. Gene, v. 133, n. 1, p. 123-7, 1993.

HER, M.; CHO, D.-H.; KANG, S.-I.; CHO, Y.-S.; HWANG, I.-Y.; BAE, Y.-C.; YOON, H.; HEO, Y.-R.; JUNG, S.-C.; YOO, H. The development of a selective medium for the Brucella abortus strains and its comparison with the currently recommended and used medium.

Diagnostic Microbiology and Infectious Disease, v. 67, n. 1, p. 15-21, 2010.

HOLLETT, R. B. Canine brucellosis: outbreaks and compliance. Theriogenology, v. 66, n. 3, p. 575-587, 2006.

JOHNSON, C. A.; WALKER, R. D. Clinical signs and diagnosis of Brucella canis infection. The Compendium on Continuing Education for Practicing Veterinarian. Small Animal, v. 16, n. 6, p. 763-772, 1992.

JONES, R. L.; EMERSON, J. K. Canine brucellosis in a commercial breeding kennel.

Journal of the American Veterinary Medical Association, v. 184, n. 7, p. 834-835, 1984.

KEID, L. B.; CHIEBAO, D. P.; BATINGA, M. C. A.; FAITA, T.; DINIZ, J. A.; OLIVEIRA, T. M. F. DE S.; FERREIRA, H. L.; SOARES, R. M. Brucella canis infection in dogs from commercial breeding kennels in Brazil. Transboundary and Emerging Diseases, v. 64, n. 3, p. 691-697, 2017. 
KEID, L. B.; MORAES, Z. M.; MELVILLE, P. A.; VASCONCELLOS, S. A. Ocorrência da brucelose canina causada por Brucella canis em canis do Estado de São Paulo. Arquivos do Instituto Biológico, v. 69, p. 42, 2002.

KEID, L. B.; SOARES, R. M.; MORAIS, Z. M.; RICHTZENHAIN, L. J.; VASCONCELLOS, S. A. Brucella spp. isolation from dogs from commercial breeding kennels in São Paulo state, Brazil. Brazilian Journal of Microbiology, v. 35, n. 1-2, p. 161166, 2004.

KEID, L. B.; SOARES, R. M.; VASCONCELlOS, S. A.; CHIEBAO, D. P.; MEGID, J.; SALGADO, V. R.; RICHTZENHAIN, L. J. A polymerase chain reaction for the detection of Brucella canis in semen of naturally infected dogs. Theriogenology, v. 67, n. 7, p. 12031210, $2007 \mathrm{~b}$.

KEID, L. B.; SOARES, R. M.; VASCONCELLOS, S. A.; CHIEBAO, D. P.; SALGADO, V. R.; MEGID, J.; RICHTZENHAIN, L. J. A polymerase chain reaction for detection of Brucella canis in vaginal swabs of naturally infected bitches. Theriogenology, v. 68, n. 9, p. 1260-1270, 2007a.

KEID, L. B.; SOARES, R. M.; VIEIRA, N. R.; MEGID, J.; SALGADO, V. R.; VASCONCELLOS, S. A.; DA COSTA, M.; GREGORI, F.; RICHTZENHAIN, L. J. Diagnosis of canine brucellosis: Comparison between serological and microbiological tests and a PCR based on primers to 16S-23S rDNA interspacer. Veterinary Research Communications, v. 31, n. 8, p. 951-965, 2007c.

KEID, L. B.; SOARES, R. M.; VASCONCELLOS, S. A.; MEGID, J.; SALGADO, V. R.; RICHTZENHAIN, L. J. Comparison of agar gel immunodiffusion test, rapid slide agglutination test, microbiological culture and PCR for the diagnosis of canine brucellosis. Research in veterinary science, v. 86, n. 1, p. 22-26, 2009.

KEID, L.; DINIZ, J.; OLIVEIRA, T.; FERREIRA, H.; SOARES, R. Evaluation of an Immunochromatographic Test to the Diagnosis of Canine Brucellosis Caused by Brucella canis. Reproduction in Domestic Animals, v. 50, n. 6, p. 939-944, 2015.

KERWIN, S. C.; LEWIS, D. D.; HRIBERNIK, T. N.; PARTINGTON, B.; HOSGOOD, G.; EILTS, B. E. Diskospondylitis associated with Brucella canis infection in dogs: 14 cases (1980-1991). Journal of the American Veterinary Medical Association, v. 201, n. 8, p. 1253-7, 1992.

KIM, J. W.; LEE, Y. J.; HAN, M. Y.; BAE, D. H.; JUNG, S. C.; OH, J. S.; HA, G. W.; CHO, B. K. Evaluation of immunochromatographic assay for serodiagnosis of Brucella canis. The Journal of veterinary medical science / the Japanese Society of Veterinary Science, v. 69, n. 11, p. 1103-7, 2007.

KIM, S.; LEE, D. S.; SUZUKI, H.; WATARAI, M. Detection of Brucella canis and Leptospira interrogans in canine semen by multiplex nested PCR. The Journal of veterinary medical science / the Japanese Society of Veterinary Science, v. 68, n. 6, p. 615-8, 2006. 
LAGE, A. P.; ROXO, E.; MÜLLER, E.; POESTER, F.; CAVALLÉRO, J C M FERREIRA NETO, J S MOTA, P M P C GONÇALVES, V. S. P. Programa nacional de controle e erradicação da brucelose e da tuberculose animal (PNCEBT). 1. ed. Brasília - DF: Ministério da Agricultura, Pecuária e Abastecimento, 2006.

LARSSON, M. H. M. A.; LARSSON, C. E.; COSTA, E. O.; GUERRA, J. L.; HAGIWARA, M. Brucelose canina experimental: Estudo Bacteriológico, Sorológico e Anatomopatológico. Arquivo Brasileiro de Medicina Veterinária e Zootecnia, v. 36, p. 141-156, 1984.

LETESSON, J. J.; TIBOR, A.; VAN EYNDE, G.; WANSARD, V.; WEYNANTS, V.; DENOEL, P.; SAMAN, E. Humoral immune responses of Brucella-infected cattle, sheep, and goats to eight purified recombinant Brucella proteins in an indirect enzyme-linked immunosorbent assay. Clinical and diagnostic laboratory immunology, v. 4, n. 5, p. 55664, 1997.

LOPES, E. G.; SEVÁ, A. P.; FERREIRA, F.; NUNES, C. M.; KEID, L. B.; HIRAMOTO, R. M.; FERREIRA, H. L.; OLIVEIRA, T. M. F. S.; BIGOTTO, M. F. D.; GALVIS-OVALLOS, F.; GALATI, E. A. B.; SOARES, R. M. Serological and molecular diagnostic tests for canine visceral leishmaniasis in Brazilian endemic area: one out of five seronegative dogs are infected. Epidemiology and Infection, v. 145, n. 12, p. 2436-2444, 2017.

LUCERO, N. E.; CORAZZA, R.; ALMUZARA, M. N.; REYNES, E.; ESCOBAR, G. I.; BOERI, E.; AYALA, S. M. Human Brucella canis outbreak linked to infection in dogs. Epidemiology and infection, v. 138, n. 2, p. 280-285, 2010a.

LUCERO, N. E.; ESCOBAR, G. I.; AYALA, S. M.; JACOB, N. Diagnosis of human brucellosis caused by Brucella canis. Journal of medical microbiology, v. 54, n. 5, p. 457461, 2005a.

LUCERO, N. E.; JACOB, N. O.; AYALA, S. M.; ESCOBAR, G. I.; TUCCILLO, P.; JACQUES, I. Unusual clinical presentation of brucellosis caused by Brucella canis. Journal of medical microbiology, v. 54, n. 5, p. 505-508, 2005 b.

LUCERO, N. E.; MALDONADO, P. I.; KAUFMAN, S.; ESCOBAR, G. I.; BOERI, E.; JACOB, N. R. Brucella canis causing infection in an HIV-infected patient. Vector borne and zoonotic diseases (Larchmont, N.Y.), v. 10, n. 5, p. 527-529, 2010 b.

MALEK DOS REIS, C. B.; HOFFMANN, R. C.; SANTOS, REGINA DA SILVA TURRI, R. DE J. G.; ORIANI, M. R. DE; GODOY. Pesquisa de anticorpos anti-Brucella canis e antiBrucella abortus em cães errantes da cidade de São João da Boa Vista, Estado de São Paulo, Brasil (2002-2003). Brazilian Journal of Veterinary Research and Animal Science, v. 45, n. 1, p. 32-34, 2008.

MANCILLA, M.; ULLOA, M.; LÓPEZ-GOÑI, I.; MORIYÓN, I.; MARÍA ZÁRRAGA, A. Identification of new IS711 insertion sites in Brucella abortus field isolates. BMC Microbiology, v. 11, n. 1, p. 176, 2011. 
MARÍN, C. M.; ALABART, J. L.; BLASCO, J. M. Effect of antibiotics contained in two Brucella selective media on growth of Brucella abortus, B. melitensis, and B. ovis. Journal of clinical microbiology, v. 34, n. 2, p. 426-8, 1996.

MATEU-DE-ANTONIO, E. M.; MARTÍN, M.; SOLER, M. Use of indirect enzyme-linked immunosorbent assay with hot saline solution extracts of a variant (M-) strain of Brucella canis for diagnosis of brucellosis in dogs. American journal of veterinary research, v. 54, n. 7, p. 1043-6, 1993.

MEGID, J.; SALGADO, V. R.; KEID, L. B.; SIQUEIRA, A. K.; CRUZ, T. F. DA; GRINSPAN, J.; LISTONI, F. J. P.; PAES, A. C. Abortamento canino por Brucella canis: relato de caso. Veterinária e Zootecnia, v. 15, n. 3, p. 445-448, 2008.

MELO, S. M. B.; NASCIMENTO, R. M.; AGUIAR, P. H. P.; FREIRE, S. M. F. Avaliação sorológica em gel de agarose para diagnóstico de Brucella canis em cães no distrito de Monte Gordo - Camaçari - Bahia. Arquivo da Escola de Medicina Veterinária da Universidade Federal da Bahia, v. 19, n. 1, p. 119-127, 1997.

METCALF, H. E.; LUCHSINGER, D. W.; RAY, W. C. Brucellosis. In: BERAN, G. W.; STEELE, J. H. (Eds.). . Handbook series in zoonoses: section A, bacterial, rickettsial, chlamydial, and mycotic. 2. ed. Boca Raton: CRC Press, 1994. p. 9-39.

MINHARRO, S.; PINTO, A.; LEITE, K. Diagnóstico da brucelose canina: dificuldades e estratégias. Revista Brasileira de Reprodução Animal, v. 29, n. 3/4, p. 167-173, 2005.

MIRANDA, K. L.; COTTORELlO, A. C. P.; POESTER, F. P.; LAGE, A. P. Brucelose canina. Caderno Técnico de Veterinária e Zootecnia, n. 47, p. 66-82, 2005.

MORAES, C. C. G.; MEGID, J.; SOUZA, L. C.; CROCCI, A. J. Prevalência da brucelose canina na microrregião da serra de Botucatu, São Paulo, Brasil. Arquivos do Instituto Biológico, v. 69, n. 2, p. 7-10, 2002.

MORAES, I. A. DE; LARANJA, H. F.; VIEIRA, D. K.; LOPES, S. P.; FREAZA, A.; MELO, G.; PENCHEL, V. Identificação de cães potencialmente transmissores de brucelose na Zona Oeste da cidade do Rio de Janeiro. Revista Brasileira Ciência Veterinária, v. 9, n. 3, p. $154-157,2002$.

MORISSET, R.; SPINK, W. W. Epidemic canine brucellosis due to a new species, Brucella canis. The Lancet, v. 294, n. 7628, p. 1000-1002, 1969.

MULLIS, K. B. The unusual origin of the polymerase chain reaction. Scientific American, v. 262, n. 4, p. 56-61, 64-5, 1990.

MYERS, D. M.; VARELA-DÍAZ, V. M.; COLTORTI, E. A. Comparative sensitivity of geldiffusion and tube agglutination tests for the detection of Brucella canis antibodies in experimentally infected dogs. Applied microbiology, v. 28, n. 1, p. 1-4, 1974.

NETO, A. M.; CORÇÃO, G.; DASSO, M. G.; KEID, L. B.; COSTA, M. DA. Antimicrobial 
susceptibility profile of Brucella spp. isolated in brazil. Revista de Patologia Tropical, v. 43, n. 2, 2014.

NIELSEN, K.; DUNCAN, J. R. Animal Brucelosis. Boca Raton: CRC Press, 1990.

NOMURA, A.; IMAOKA, K.; IMANISHI, H.; SHIMIZU, H.; NAGURA, F.; MAEDA, K.; TOMINO, T.; FUJITA, Y.; KIMURA, M.; STEIN, G. H. Human Brucella canis infections diagnosed by blood culture. Emerging Infectious Diseases, v. 16, n. 7, p. 1183-1185, 2010.

OCAMPO-SOSA, A. A.; GARCÍA-LOBO, J. M. Demonstration of IS711 transposition in Brucella ovis and Brucella pinnipedialis. BMC Microbiology, v. 8, n. 1, p. 17, 2008.

OIE. Ovine Epididymitis (Brucella ovis)Manual of Diagnostic Tests and Vaccines for Terrestrial Animals 2015, 2015. Disponível em: <http://www.oie.int/international-standardsetting/terrestrial-manual/access-online/>

OUAHRANI, S.; MICHAUX, S.; WIDADA, J. S.; BOURG, G.; TOURNEBIZE, R.; RAMUZ, M.; LIAUTARD, J.-P. Identification and sequence analysis of IS6501, an insertion sequence in Brucella spp.: relationship between genomic structure and the number of IS6501 copies. Journal of General Microbiology, v. 139, n. 12, p. 3265-3273, 1993.

PAULIN, L. M.; FERREIRA NETO, J. S. O combate à brucelose bovina. 1. ed. Jaboticabal: FUNEP, 2003.

PETRIE, A.; WATSON, P. Statistics for veterinary and animal science. Oxford, Malden: Blackwell Science, 1999. 243 p.

PICKERILL, P. A.; CARMICHAEL, L. E. Canine brucellosis: control programs in commercial kennels and effect on reproduction. Journal of the American Veterinary Medical Association, v. 160, n. 12, p. 1607-1615, 1972.

POLT, S. S.; DISMUKES, W. E.; FLINT, A.; SCHAEFER, J. Human brucellosis caused by Brucella canis: clinical features and immune response. Annals of internal medicine, v. 97, n. 5, p. 717-719, 1982.

QUINN, P. J.; CARTER, M. E.; MARKEY, B.; CARTER, G. R. Clinical veterinary microbiology. London: Wolfe Publishing, 1994.

REDKAR, R.; ROSE, S.; BRICKER, B.; DELVECCHIO, V. Real-time detection of Brucella abortus, Brucella melitensis and Brucella suis. Molecular and cellular probes, v. 15, n. 1, p. 43-52, 2001.

RHOADES, H. E.; MESFIN, G. M. Brucella canis infection in a kennel. Veterinary medicine, small animal clinician : VM, SAC, v. 75, n. 4, p. 595-9, 1980.

ROUSSEAU, P. Brucella canis infection in a woman with fever of unknown origin. Postgraduate medicine, v. 78, n. 5, p. 249, 253-254, 257, 1985.

ROXO, E.; PINHEIRO, S. R.; BRANDÃO, M. M.; AGUIAR, J. A. C.; GOUVÊA, G.; 
PIORUM, M. L.; LIMA, M. A. B. Brucelose canina: relato de uma possivel transmissão de Brucella canis ao homen a partir de uma cadela da raça Doberman. Arquivos do Instituto Biológico, v. 55, n. 19, p. 1-4, 1990.

SALDARRIAGA, O. A.; OSSA, J. E. Respuesta inmune y estrategias de evasión durante la infección con Brucella spp . Revista Colombiana de Ciências Pecuárias, v. 15, n. 38, p. 180-187, 2002.

SALGADO, V. R. Avaliação das técnicas de cultivo microbiológico e soroaglutinação rápida em cartão com e sem 2-mercaptoetanol no diagnóstico da brucelose canina.

Dissertação (mestrado) - Universidade Estadual Paulista, Faculdade de Medicina Veterinária e Zootecnia, Botucatu, 2006, 114 pp.

SAMBROOK, J.; FRITSCH, E. F.; MANIATIS, T. Molecular cloning: a laboratory manual. 2.ed. Cold Spring Harbor: Cold Spring Harbor Laboratory Press, 1989.

SCHOLZ, H. C. et al. Brucella microti sp. nov., isolated from the common vole Microtus arvalis. International journal of systematic and evolutionary microbiology, v. 58, n. Pt 2, p. 375-382, 2008.

SCHOLZ, H. C.; HUBALEK, Z.; NESVADBOVA, J.; TOMASO, H.; VERGNAUD, G.; LE FLÈCHE, P.; WHATMORE, A. M.; AL DAHOUK, S.; KRÜGER, M.; LODRI, C.;

PFEFFER, M. Isolation of Brucella microti from soil. Emerging Infectious Diseases, v. 14, n. 8, p. 1316-1317, 2008.

SCHOLZ, H. C.; MÜHLDORFER, K.; SHILTON, C.; BENEDICT, S.; WHATMORE, A. M.; BLOM, J.; EISENBERG, T. The change of a medically important genus: Worldwide occurrence of genetically diverse novel Brucella species in exotic frogs. PLOS ONE, v. 11, n. 12, p. e0168872, 2016.

SCHOLZ, H. C.; NÖCKLER, K.; GÖLLNER, C.; BAHN, P.; VERGNAUD, G.; TOMASO, H.; AL DAHOUK, S.; KÄMPFER, P.; CLOECKAERT, A.; MAQUART, M.; ZYGMUNT, M. S.; WHATMORE, A. M.; PFEFFER, M.; HUBER, B.; BUSSE, H.-J.; DE, B. K. Brucella inopinata sp. nov., isolated from a breast implant infection. International journal of systematic and evolutionary microbiology, v. 60, n. Pt 4, p. 801-808, 2010.

SCHOLZ, H. C.; REVILLA-FERNÁNDEZ, S.; AL DAHOUK, S.; HAMMERL, J. A.; ZYGMUNT, M. S.; CLOECKAERT, A.; KOYLASS, M.; WHATMORE, A. M.; BLOM, J.; VERGNAUD, G.; WITTE, A.; AISTLEITNER, K.; HOFER, E. Brucella vulpis sp. nov., isolated from mandibular lymph nodes of red foxes (Vulpes vulpes). International journal of systematic and evolutionary microbiology, v. 66, n. 5, p. 2090-8, 2016.

SERIKAWA, T.; MURAGUCHI, T. Significance of urine in transmission of canine brucellosis. Nihon juigaku zasshi. The Japanese journal of veterinary science, v. 41, n. 6 , p. $607-16,1979$.

SILVA, C. P. A. E; ALMEIDA, A. DO B. P. F. DE; GODOY, I. DE; ARAÚJO, A. C. P. DE; 
AGUIAR, D. M. DE; SOUSA, V. R. F.; NAKAZATO, L.; DUTRA, V. Detecção molecular de Brucella canis em cães do Município de Cuiabá, Estado de Mato Grosso. Ciência Rural, v. 42, n. 6, p. 1051-1056, 2012.

SMEAK, D. D.; OLMSTEAD, M. L.; HOHN, R. B. Brucella canis osteomyelitis in two dogs with total hip replacements. Journal of the American Veterinary Medical Association, v. 191, n. 8, p. 986-990, 1987.

STOENNER, H. G.; LACKMAN, D. B. A new species of Brucella isolated from the desert wood rat, Neotoma lepida Thomas. American journal of veterinary research, v. 18, n. 69, p. 947-951, 1957.

TSOGTBAATAR, G.; TACHIBANA, M.; WATANABE, K.; KIM, S.; SUZUKI, H.; WATARAI, M. Enzyme-linked immunosorbent assay for screening of canine brucellosis using recombinant cu-zn superoxide dismutase. J Vet.Med.Sci., v. 70, n. 12, p. 1387-1389, 2008.

VASCONCELOS, R. T. J.; ALVES, C. J.; CLEMENTINO, I. J.; ARAÚJO NETO, J. O.; ALVES, F. A. L.; BATISTA, C. S. A.; BERNARDI, F.; SOTO, F. R. M.; OLIVEIRA, R. M.; AZEVEDO, S. S. Soroprevalência e fatores de risco associados à infecção por Brucella canis em cães da cidade de Campina Grande, estado da Paraíba. Revista Brasileira de Saúde e Produção Animal, v. 9, p. 436-442, 2008.

VICENTE, A. F.; ANTUNES, J. M. A. P.; LARA, G. H. B.; MIONI, M. S. R.; ALLENDORF, S. D.; PERES, M. G.; APPOLINÁRIO, C. M.; LISTONI, F. J. P.; RIBEIRO, M. G.; MEGID, J. Evaluation of three formulations of culture media for isolation of Brucella spp. regarding their ability to inhibit the growth of contaminating organisms. BioMed

Research International, v. 2014, p. 1-3, 2014.

VIZCAÍNO, N.; CLOECKAERT, A.; VERGER, J.; GRAYON, M.; FERNÁNDEZ-LAGO, L. DNA polymorphism in the genus Brucella. Microbes and infection / Institut Pasteur, v. 2, n. 9, p. 1089-1100, 2000.

WALLACH, J. C.; GIAMBARTOLOMEI, G. H.; BALDI, P. C.; FOSSATI, C. A. Human infection with M- strain of Brucella canis. Emerging infectious diseases, v. 10, n. 1, p. 146$148,2004$.

WANKE, M.; DELPINO, M.; BALDI, P. Comparative performance of tests using cytosolic or outer membrane antigens of Brucella for the serodiagnosis of canine brucellosis.

Veterinary microbiology, v. 88, p. 367-375, 2002.

WANKE, M. M. Canine brucellosis. Animal reproduction science, v. 82-83, p. 195-207, 2004.

WANKE, M. M.; CAIRÓ, F.; ROSSANO, M.; LAIÑO, M.; BALDI, P. C.; MONACHESI, N. E.; COMERCIO, E. A; VIVOT, M. M. Preliminary study of an immunochromatography test for serological diagnosis of canine brucellosis. Reproduction in domestic animals = 
Zuchthygiene, v. 47 Suppl 6, p. 370-2, 2012.

WHATMORE, A. M.; DAVISON, N.; CLOECKAERT, A.; AL DAHOUK, S.; ZYGMUNT, M. S.; BREW, S. D.; PERRETT, L. L.; KOYLASS, M. S.; VERGNAUD, G.; QUANCE, C.; SCHOLZ, H. C.; DICK, E. J.; HUBBARD, G.; SCHLABRITZ-LOUTSEVITCH, N. E. Brucella papionis sp. nov., isolated from baboons (Papio spp.). INTERNATIONAL JOURNAL OF SYSTEMATIC AND EVOLUTIONARY MICROBIOLOGY, v. 64, n. Pt 12, p. 4120-4128, 2014.

WILSON, K. Preparation of genomic DNA from bacteria. In: F.M. Ausubel, R. Brent, R.E. Kimgston, et al. (eds), Current Protocols in Molecular Biology, (Greene Publishing Associates/John Wiley and Sons, New York), 241-245, 1990.

WOOLEY, R. E.; HITCHCOCK, P. L.; BLUE, J. L.; NEUMAN, M. A.; BROWN, J.; SHOTTS, E. B. Isolation of Brucella canis from a dog seronegative for brucellosis. Journal of the American Veterinary Medical Association, v. 173, n. 4, p. 387-388, 1978.

YAGUPSKY, P. Detection of Brucellae in blood cultures. Journal of clinical microbiology, v. 37, n. 11, p. 3437-42, 1999.

YANG, S.; ROTHMAN, R. E. PCR-based diagnostics for infectious diseases: uses, limitations, and future applications in acute-care settings. The Lancet. Infectious diseases, v. 4, n. 6, p. 337-48, 2004.

ZOHA, S. J.; CARMICHAEL, L. E. Serological responses of dogs to cell wall and internal antigens of Brucella canis (B. canis). Veterinary microbiology, v. 7, n. 1, p. 35-50, 1982.

ZYGMUNT, M.; BAUCHERON, S. Single-step purification and evaluation of recombinant BP26 protein for serological diagnosis of Brucella ovis infection in rams. Veterinary microbiology, v. 87, p. 213-220, 2002. 